K/NSP-778

\title{
Proliferation Potential of Accelerator-Driven Systems: Feasibility Calculations
}

\author{
Christine D. Riendeau \\ U.S. Department of Energy \\ David L. Moses \\ Oak Ridge National Laboratory \\ Arne P. Olson \\ Argonne National Laboratory
}

Contributions by Arvid S. Lundy of Los Alamos National Laboratory; Richard A. Lillie, James D. Drischler, Jess C. Gehin, Jeffry O. Johnson of Oak Ridge National Laboratory; and Richard S. Goorevich of the U.S. Department of Energy

November 1998

(Distributed June 1999)

\author{
Prepared for \\ U.S. Department of Energy \\ Office of Arms Control and Nonproliferation \\ Nuclear Transfer and Supplier Policy Division (NN-43)

\section{Prepared by \\ NATIONAL SECURITY PROGRAM OFFICE} \\ Oak Ridge Y-12 Plant \\ Oak Ridge, Tennessee 37831-8206 \\ managed by \\ Lockheed Martin Energy Systems, Inc. \\ for the \\ U.S. Department of Energy \\ under contract DE-AC05-84OR21400
}





\section{DISCLAIMER}

This report was prepared as an account of work sponsored by an agency of the United States Government. Neither the United States Government nor any agency thereof, nor any of their employees, make any warranty, express or implied, or assumes any legal liability or responsibility for the accuracy, completeness, or usefulness of any information, apparatus, product, or process disclosed, or represents that its use would not infringe privately owned rights. Reference herein to any specific commercial product, process, or service by trade name, trademark, manufacturer, or otherwise does not necessarily constitute or imply its endorsement, recommendation, or favoring by the United States Government or any agency thereof. The views and opinions of authors expressed herein do not necessarily state or reflect those of the United States Government or any agency thereof. 


\section{DISCLAIMER}

Portions of this document may be illegible in electronic image products. Images are produced from the best available original document. 


\section{Contents}

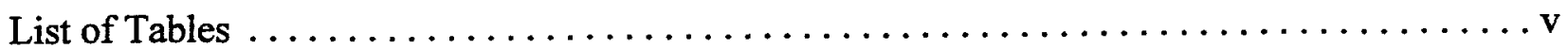

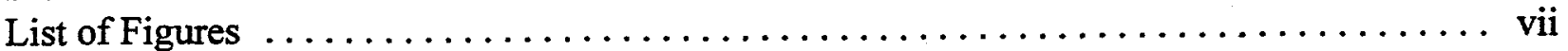

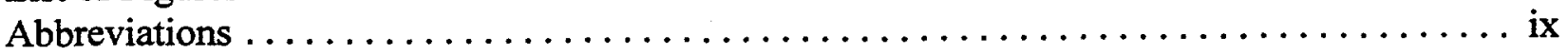

Executive Summary $\ldots \ldots \ldots \ldots \ldots \ldots \ldots \ldots \ldots \ldots \ldots \ldots \ldots \ldots \ldots \ldots \ldots \ldots \ldots$

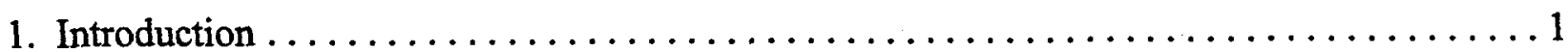

2. Historical Perspective on Fertile-to-Fissile Materials Conversion and Breeding

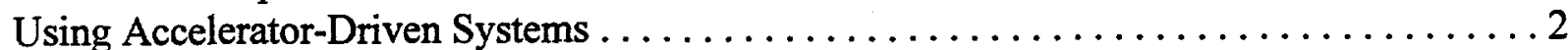

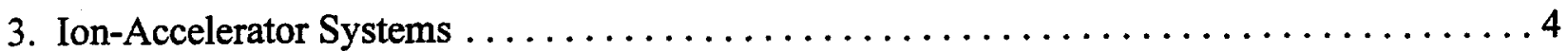

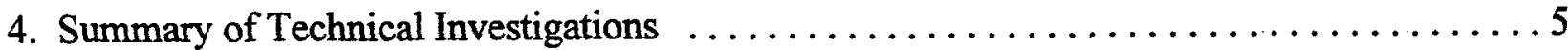

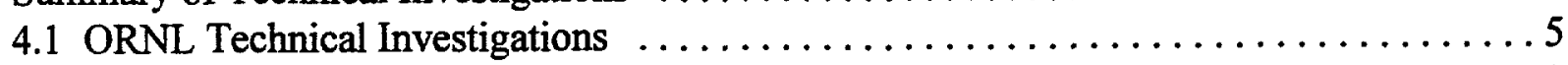

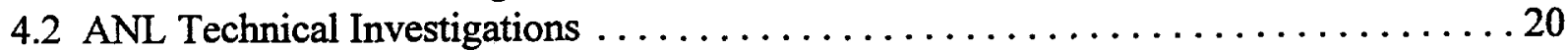

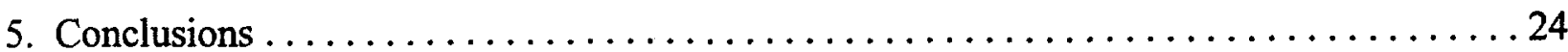

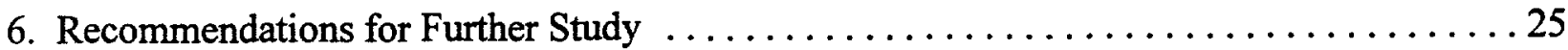

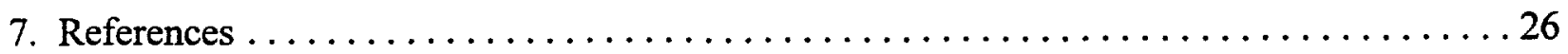





\section{List of Tables}

1 Optimal infinite cell parameters for water-moderated and graphite-moderated

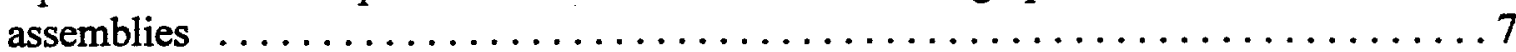

2 Subcritical source neutron multiplication and ${ }^{238} U$ capture rate in a central-source-driven Hanford graphite-moderated, water-cooled lattice

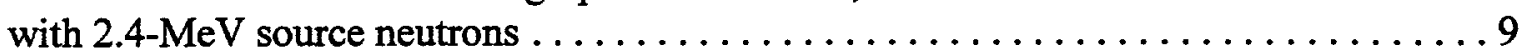

3 Effect of neutron source energy on ${ }^{238} \mathrm{U}$ capture rate in an 8-ft (2.44-m) cubic pile with a central-source-driven Hanford graphite-moderated,

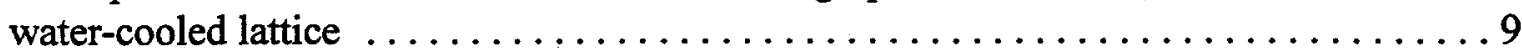

4 Uranium-238 captures per $2.5-\mathrm{MeV}$ source neutron in different blanket assemblies . . 11

$5 \quad$ Average ${ }^{238} \mathrm{U}$ captures per source neutron in three blanket assemblies for $150-\mathrm{MeV}$ and $1-\mathrm{GeV}$ protons incident on a natural uranium target $\ldots \ldots \ldots \ldots . .14$

6 Minimum estimates of accelerator current and beam power requirements

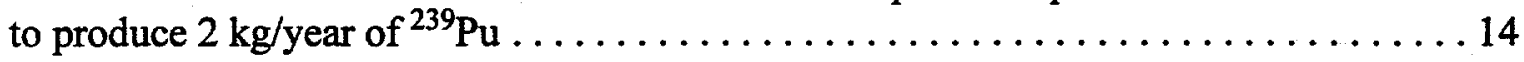

7 Mass in metric tons of natural uranium metal fuel required in graphite-moderated and water-moderated assemblies as a function of pile size $\ldots \ldots \ldots \ldots \ldots \ldots \ldots 15$

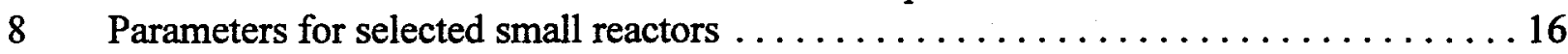

9 Estimates of minimum accelerator current and beam power requirements to produce $2 \mathrm{~kg} /$ year of ${ }^{239} \mathrm{Pu}$ in a subcritical pile loaded with 25 metric tons

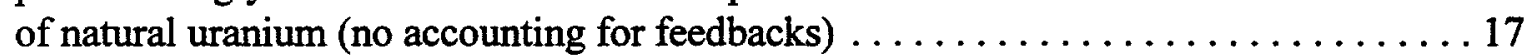

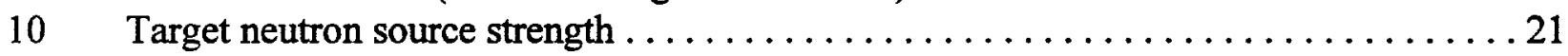

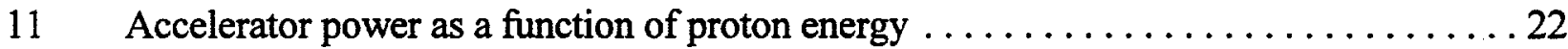

12 Spherical subcriticals: $k_{\text {eff }}$ for various loadings of uranium $\ldots \ldots \ldots \ldots \ldots \ldots 23$

13 Spherical subcriticals: multiplication $(M)$ for various loadings of uranium $\ldots \ldots \ldots 23$ 



\section{List of Figures}

1 Uranium-238 captures per source neutron in a graphite-moderated natural uranium lattice with $5 \mathrm{ppm}$ natural boron in graphite and a $1.5-\mathrm{mm} \mathrm{CO} \mathrm{CO}_{2}$ gap between 0.9 and $1.6 \mathrm{~mm}$ of aluminum cladding

2 Uranium-238 captures per source neutron in a graphite-moderated natural uranium lattice with $5 \mathrm{ppm}$ natural boron in graphite and a $1.5-\mathrm{mm} \mathrm{H}_{2} \mathrm{O}$ gap

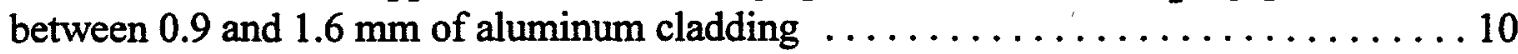

3 Uranium-238 captures per source neutron in a water-moderated natural uranium lattice

4 Uranium-238 capture rate divided by subcritical source multiplication (5 ppm natural boron in graphite, $1.5-\mathrm{mm} \mathrm{CO}_{2}$ gap between 0.9 and $1.6 \mathrm{~mm}$ of aluminum cladding) 



\section{Abbreviations}

$\mu \mathrm{A} \quad$ microampere

A ampere

ANL Argonne National Laboratory

BNL Brookhaven National Laboratory

$\mathrm{GeV}$ giga electron volts, 1,000 million electron volts

$\mathrm{kW}$ kilowatt

LASL Los Alamos Scientific Laboratory (now LANL)

LANL Los Alamos National Laboratory

LWR light water reactor

$\mathrm{mA}$ milliampere

$\mathrm{MeV}$ million electron volts

MT metric ton

MW megawatt

MWd megawatt-day

ORNL Oak Ridge National Laboratory

ppm part per million

psi pound per square inch

PWR pressurized water reactor

UCE ${ }^{238} \mathrm{U}$ capture efficiency 



\section{Executive Summary}

Accelerator-driven systems for fissile materials production have been proposed and studied since the early 1950s. Recent advances in beam power levels for small accelerators have raised the possibility that such use could be feasible for a potential proliferator. The objective of this study is to review the state of technology development for accelerator-driven spallation neutron sources and subcritical reactors. * Energy and power requirements were calculated for a proton accelerator-driven neutron spallation source and subcritical reactors to produce a significant amount of fissile material-plutonium.

This study determined lower limits on key parameters of the accelerator which affect plutonium production-namely, particle beam current (or power) and particle energy. Analyses were performed to determine the plutonium production capability of a proton accelerator as a spallation neutron source for driving neutron multiplication in a subcritical reactor containing source material. The study focused on subcritical reactors composed of natural uranium-fueled, thermal neutron lattices including those typical of both production and commercial power reactors. The technology associated with natural uranium blankets is in publicly available literature and would be readily available to proliferators. Two kilograms per year was set as the reference amount for production of plutonium in the reactor. This was chosen to coincide with the international convention for physical protection of Category I-High Strategic Significance nuclear material.

The analyses show that, depending principally upon the lattice configuration and the proton energy, accelerators with proton energies of 1.0 giga electron volts $(\mathrm{GeV})$ and operating at beam power levels of $50-100 \mathrm{~kW}$ can practicably produce $2 \mathrm{~kg} /$ year of plutonium. At lower proton energies (i.e., around $0.15 \mathrm{GeV}$ ) where the production of neutrons by spallation falls to approximately one neutron per proton, the beam power requirement rises to several hundred kilowatts to produce $2 \mathrm{~kg} /$ year of plutonium.

Medium-energy particle accelerators, including cyclotrons, are feasible for producing plutonium. Several known commercial accelerator design consultants may be capable of designing suitable systems. These accelerators need to be enhanced by higher levels of blanket multiplication in order to produce the quantities of plutonium that are of concern to this study. For small blanket lattices containing 25 metric tons (MT) of natural uranium, which is approximately the same loading

* Note on terminology: The report refers to "subcritical reactor" in describing a device that maintains an intense neutron flux level when driven by an external neutron source. It has characteristics intermediate between a conventional reactor able to sustain neutron multiplication without continuing external neutrons and a subcritical facility unable to sustain the fission process. A subcritical reactor can multiply neutrons from the external source to attain neutron flux levels and fission power otherwise attainable only in a nuclear reactor. Other related terms used in this report come from historical usage in reactor physics and engineering; they include the term "electronuclear breeder," coined in the 1950s to describe the accelerator/subcritical reactor concept, and terms describing the building blocks of reactors (e.g., "piles," "lattices"). 


\section{Minimum beam power for plutonium production of $2 \mathrm{~kg} / \mathrm{year}$ assuming no reactivity feedback in the blanket}

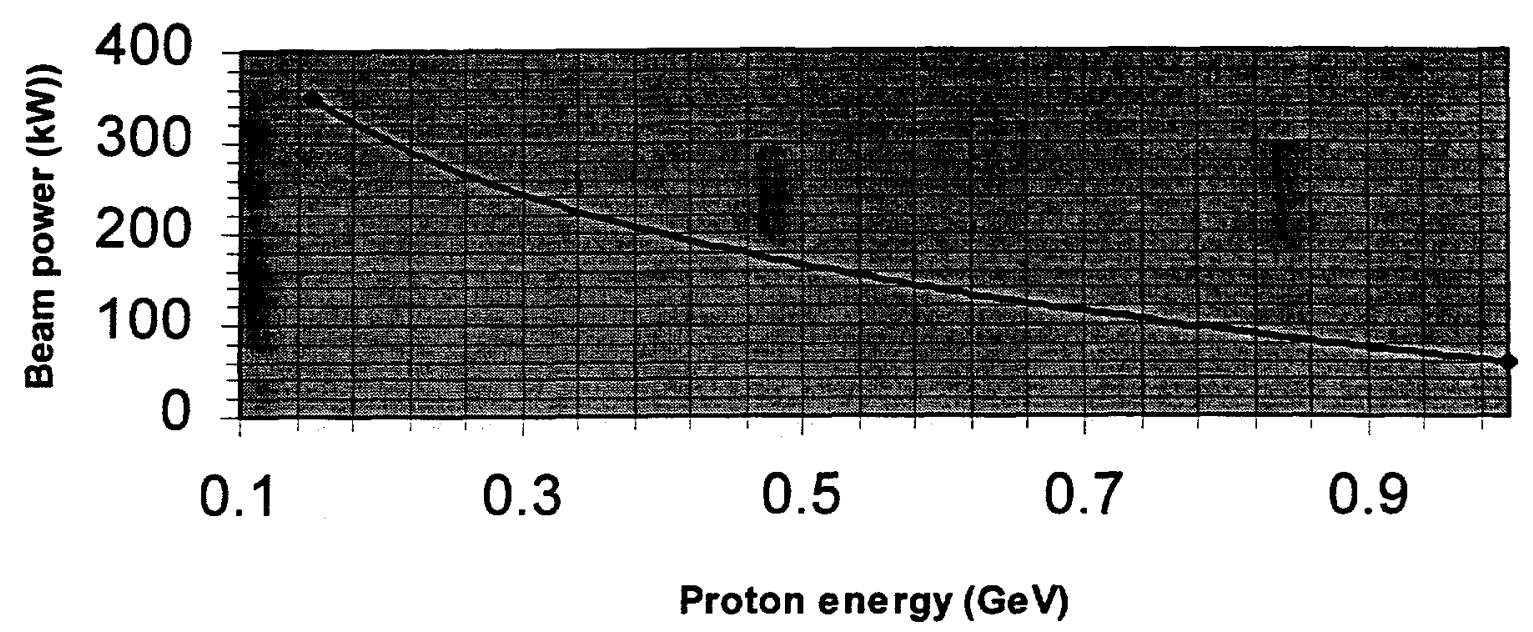

as would be expected in a small, low-power, graphite-moderated research reactor, the use of an optimally configured light-water-moderated blanket lattice produces the minimum value of required beam power. The estimated minimum beam power, as a function of beam energy, required to produce $2 \mathrm{~kg}$ /year of plutonium using an optimally configured, light-water-moderated lattice loaded with $25 \mathrm{MT}$ of natural uranium ranges from $60 \mathrm{~kW}$ at $1 \mathrm{GeV}$ to $350 \mathrm{~kW}$ at $0.15 \mathrm{GeV}$. No accounting has been made for small negative reactivity feedbacks that tend to increase the required beam power to compensate for reduced lattice multiplication. The estimate of minimum beam power depicted in the figure provides a lower bound for the accelerator required to drive a subcritical production lattice that would be of a size and uranium mass nearest that of the smallest critical production reactor using graphite as a moderator.

The authors believe that the calculations presented herein are of sufficient accuracy for the purposes of the present study. However, other factors to take into account for further refinement of the calculations are technical aspects of the target design (such as net neutron production from spallation, multiplication of neutrons in target material, and the target system neutron leakage) and of the blanket design (such as blanket lattice multiplication; plutonium production efficiency, in the blanket lattice; and reactivity feedbacks in the blanket, including xenon-135 production and increased temperatures if the blanket is operated at high power densities).

The analyses suggest that production of significant quantities of plutonium with a proton accelerator-driven system may be feasible for a proliferant nation, given the estimated beam energy level and power requirements. Additional aspects to consider in an overall feasibility assessment include critical equipment and technologies required for such systems and their overall availability, either through indigenous development or importation, to a proliferant nation. 


\section{Introduction}

Accelerator applications in basic scientific research and isotope production have led to advances in the beam power levels attainable in smaller units. An accelerator-driven spallation neutron source coupled with a subcritical assembly of source material is capable of producing fissile material for nuclear weapons. Because recent advances in the field of accelerator design have led to smaller, more capable accelerators, concerns have been raised regarding possible uses of accelerators in programs of proliferation concern. Large-scale accelerators may potentially be used as the key component of an electronuclear breeder facility, which is a combination of a subcritical reactor and a strong neutron source created by an accelerator-driven neutron spallation source; advanced nuclear nations in Europe and elsewhere are currently evaluating such concepts. The technology for building subcritical reactors composed of natural uranium-fueled thermal neutron lattices including those typical of both production and commercial power reactors with natural uranium blankets is in the public domain and would be readily available to proliferators.

The Nuclear Transfer and Supplier Policy Division of the U.S. Department of Energy is conducting a study of the proliferation potential of accelerator systems drawing upon technical staff of Argonne National Laboratory (ANL), Los Alamos National Laboratory (LANL), and Oak Ridge National Laboratory (ORNL). The team was tasked to provide approximate estimates of the requirements for an accelerator to produce $2 \mathrm{~kg}$ of plutonium-239 $\left({ }^{239} \mathrm{Pu}\right)$ per year. Two kilograms per year was chosen to agree with the amount of plutonium recognized by international convention for physical protection as Category I-High Strategic Significance material (Annex II, "Categorization of Nuclear Material," INFCIRC/274/Rev. 1, May 1980).

The specific thrust of the present effort has been to perform analyses of a number of possible accelerator systems with and without subcritical reactors. This report presents an overview of the first phase of the accelerator study. The conclusions thus far are presented after describing the assumptions and analysis techniques used by ORNL and ANL in their independent work. 


\section{Historical Perspective on Fertile-to-Fissile Materials Conversion and Breeding Using Accelerator-Driven Systems}

The use of accelerator-driven systems to convert fertile materials into fissile materials or to breed fissile materials is not a new idea. The first man-made plutonium was produced in 1940 using a deuteron accelerator and a natural uranium target. The work of E. O. Lawrence and others at Livermore starting in 1947 led the United States to sponsor an initially classified project directed toward building an accelerator for the production of weapon-grade fissile material in competition at the time with proposed new production reactors then planned for Hanford and Savannah River [1]. The MTA (or Materials Testing Accelerator) Project [2] ended in 1954 when it was concluded by the U.S. Atomic Energy Commission that the technology was not available at that time to build such a device. The project documentation was declassified in 1957. Starting in the 1950 s and into the 1980 s, Canada studied the possibility of energy production and breeding in accelerator-driven (or electronuclear) subcritical fast reactors [3-5]. Russian scientists initiated studies of the feasibility of electronuclear fuel production in the late 1960s and early 1970s [6, 7]. In the 1970s and 1980s, similar studies of accelerator-driven fast breeders were conducted by the United States [1] at its National Laboratories, including Argonne [8], Brookhaven [9, 11], Lawrence Livermore [12], Los Alamos [13, 14] and Oak Ridge [15-17]. Today, some of the U.S. National Laboratories [18], Russia [19], Europe [20], Japan [21], and South Korea are studying very similar accelerator-driven fast neutron target/blanket systems for various other missions, including plutonium disposition and actinide waste transmutation [22].

The results of U.S. studies in the late 1970s determined that an accelerator-driven sodiumcooled fast breeder blanket of stainless steel-clad uranium oxide pellets would be capable of producing about $1000 \mathrm{~kg} / \mathrm{year}$ of plutonium but would require an accelerator producing $1.0-\mathrm{GeV}$ protons at a current of $300 \mathrm{~mA}$ with a total power requirement for the facility of $628 \mathrm{MW}$ (300 MW in the beam). Currently, both Europe and the United States are designing new 1.0- to $1.3-\mathrm{GeV}$ proton research accelerators as pulsed neutron sources that are capable of operating with beam powers of 1-5 MW. The United States and France are also both developing high-power accelerators for tritium production $[23,24]$. The initial concept for the U.S. design of a tritium production accelerator was based on using a $1.0-\mathrm{GeV}$ proton, $200-\mathrm{mA}$ beam capable of operating at a continuous beam power of $200 \mathrm{MW}$. That concept is now reportedly being changed to a $1.7-\mathrm{GeV}$ proton, $100-\mathrm{mA}$ beam capable of operating at a continuous beam power of $170 \mathrm{MW}$ but producing approximately the same net number of neutrons from primary and secondary spallation due to the higher particle energy. Although the planned accelerator projects approach the levels of beam power needed for producing significant quantities of plutonium in fast neutron breeder blankets, it should be noted that scaling up the beam power on an accelerator has many more uncertainties than scaling up the power on a reactor.

Recently, Russia has proposed using an accelerator as a means to dispose of plutonium. Using off-the-shelf graphite reactor technology, the Russian proposal would use an accelerator to drive a 
subcritical thermal neutron reactor $[25,26]$. What has not been addressed in previous studies of accelerator-driven fast neutron breeders or in the recent Russian proposal for an accelerator-driven thermal neutron reactor for plutonium disposition is whether an accelerator-driven, thermal neutron-multiplying converter blanket poses a proliferation risk by bypassing existing export controls on reactor materials such as nuclear-grade graphite and heavy water. In essence, it must be determined whether existing or very-near-term technologies for proton, deuteron, or heavy ion accelerators provide a sufficient neutron source to produce weapon-grade plutonium in a neutronmultiplying converter blanket of natural uranium metal moderated by non-nuclear-grade graphite or light water. 


\section{Ion-Accelerator Systems}

The principal stages of an ion-accelerator system able to produce materials for nuclear weapons are (1) the ion source/injector assembly, (2) the various acceleration stages, and (3) the postacceleration stage composed of the beam transport system and the target. Power supplies and computer-based control systems are needed to operate each of these stages. Accelerator systems have a few key parameters which best describe their capabilities succinctly: the final energy of the accelerated particle, the ion accelerated (mass and charge), and the useful average beam current. The beam power is the product of the energy of the accelerated particle and the useful average beam current. Large-scale accelerators may potentially be used as the key component of an electronuclear breeder facility, which is a combination of a subcritical reactor and a strong neutron source created by an accelerator-driven neutron spallation source to drive the reactor to high power. Like a commercial power reactor, nuclear heat from an electronuclear breeder can be turned into steam and, subsequently, into electrical power to drive the accelerator (this is known as power regeneration). In this application, protons (mass 1, charge 1) or deuterons (mass 2, charge 1) are accelerated to an energy on the order of $1 \mathrm{GeV}$ and impinge upon a suitably designed target material such as lead, lead-bismuth, mercury, uranium, or thorium. Heavy metals are most typically used as target materials due to lower nuclear binding energies with increasing atomic mass, leading to an increase in neutron yield per unit of beam energy invested.

The process of transmuting materials such as lithium into tritium, and uranium into plutonium, is very energy-intensive. If every accelerated ion were to yield a product atom, about 97,000 coulombs of electrical charge would be required to yield 1 mole of product (e.g., $3 \mathrm{~g}$ of tritium, $239 \mathrm{~g}$ of ${ }^{239} \mathrm{Pu}$ ). A coulomb [the Standard International (SI) unit of charge] is the charge carried by 1 ampere (A) in 1 second. This amount of charge can be delivered at a current of $1 \mathrm{~mA}$ in 27,000 hours, or 3.08 years. The effective yield depends on the nuclear cross sections of the processes being used. The nuclear cross sections are, in general, strongly dependent upon the energy of the accelerated ion, as well as on the choice of ion. The yield of neutrons per spallation event is roughly linear with the energy of the incident charged particle, above about $0.3 \mathrm{GeV}$. Optimization of yield per unit cost is a principal factor in choosing the energy of the output beam. For ion accelerators considered in this study, the yield of neutrons per spallation increases with energy-favoring the highest energy achievable. But one can trade off beam current with maximum beam energy: twice the beam current with half the beam energy will still produce the same yield, provided that the reduced beam energy is above about $0.3 \mathrm{GeV}$. However, as the energy of the output (accelerated) beam increases, the size of the accelerator increases, as does its fabrication and operating costs. Beam power is the product of beam current and particle energy. Therefore, an accelerator which provides a $100-\mathrm{MeV}, 0.005-\mathrm{A}$ beam, while operating at $25 \%$ efficiency, requires 2.0 MW of electrical grid power. In the beam energy range of interest for this study, at a given energy, an accelerator has a peak current beyond which it is not feasible to operate. Hence, beam current and accelerated ion energy are closely intertwined by physical design constraints, rather than being simply parameters. Advances in the state of the art continue to push the design constraints. 


\section{Summary of the Technical Investigations}

Technical investigations were performed independently by Oak Ridge National Laboratory (ORNL) and Argonne National Laboratory (ANL). The work addressed the feasibility and capability of existing and near-term accelerators to produce up to $2 \mathrm{~kg}$ of weapon-grade plutonium annually. The ORNL results were aimed at defining maximum possible yields from a few selected subcritical designs including lattices very similar to those used in previous production reactors. The ANL results were aimed at determining the performance of a very simple design using light water coolant with natural uranium oxide rods in a typical light water reactor (LWR) lattice without optimization (i.e., without designing for the best pin size, the best lattice pitch, and so forth, to maximize reactivity and subcritical multiplication). Consequently, the ORNL results predicted substantially less beam power or neutron source strength than was predicted by the ANL results to produce $2 \mathrm{~kg} /$ year. The two sets of results are therefore complementary, because the study approaches were complementary.

\subsection{ORNL Technical Investigations}

Nuclear physics calculations were performed such that rough estimates could be made of the accelerator sizes (in terms of power: particle energy times current) required to produce $2 \mathrm{~kg}$ of weapon-grade plutonium annually. Since $2 \mathrm{~kg}$ of ${ }^{239} \mathrm{Pu}$ corresponds to $5 \times 10^{24}$ atoms, a production rate of $1.6 \times 10^{17}$ atoms/second is required. In an ideal world, that is, one in which no losses of ${ }^{239} \mathrm{Pu}$ occur either because of nuclear absorption during production or because of chemical losses during reprocessing or extraction, the required neutron capture rate in uranium-238 $\left({ }^{238} \mathrm{U}\right)$ would be equal to the required production rate of ${ }^{239} \mathrm{Pu}$. Thus, without any additional neutron production through multiplication (i.e., fission neutrons), an accelerator and target capable of producing $1.6 \times 10^{17}$ neutrons/second would be required.

A current state-of-the-art, high-power, high-energy accelerator would be similar to the 1-GeV proton accelerator currently under consideration for the National Spallation Neutron Source (NSNS). An accelerator equivalent to the NSNS will be capable of producing approximately 40 neutrons from each 1-GeV proton incident on a natural uranium target [27]. If each of these neutrons were captured in ${ }^{238} \mathrm{U}$, a proton current of $640 \mu \mathrm{A}$ or an equivalent beam power of $0.64 \mathrm{MW}$ would be required to produce $2 \mathrm{~kg}$ of weapon-grade plutonium annually. On the other hand, a low-energy (but highest power offered) commercially available $150-\mathrm{MeV}$ proton accelerator producing one neutron per proton would be required to operate with a proton current of $26 \mathrm{~mA}$ and an equivalent beam power of 3.85 MW. The initial operating power of the NSNS is to be $1 \mathrm{MW}$. State-of-the-art low-energy proton accelerators operate with currents on the order of a few milliamperes. Thus, without additional neutron production or "multiplication," a high-energy accelerator design approaching current state of the art or a low-energy accelerator design an order of magnitude beyond currently available technology would be required to produce $2 \mathrm{~kg}$ of weapon-grade plutonium annually even under perfect conditions. 


\section{ORNL Study Assumptions}

ORNL technical investigations addressed (1) the neutron physics of relatively low-technology, multiplying-production blankets using unregulated moderator materials and natural uranium and (2) existing and near-term accelerators that can produce the neutron source necessary for feasible production in low-technology blankets. Use of unregulated moderator materials was assumed since potential proliferators would use accelerators to bypass the regulatory controls on nuclear-grade graphite and heavy water, which would be the preferred choices for use in production reactors.

The specific thrust of the ORNL effort was to perform a cursory, parametric analysis of a number of possible blanket or neutron multiplying assemblies subject to several constraints on the potential proliferator. These constraints are that (1) enriched uranium (at any enrichment level) is not available or attainable as a fissile material and (2) nuclear-grade graphite and/or heavy water are not available or attainable as moderating materials. Consistent with current export controls, nucleargrade graphite is defined as graphite containing less than $5 \mathrm{ppm}$ by weight of natural boron or the equivalent in terms of parasitic absorption. Five blanket assemblies were initially analyzed:

- saturated homogeneous uranyl nitrate in water assembly (actually, fully hydrated uranyl nitrate was assumed, which is more of a watery crystal than a solution);

- saturated uranyl nitrate in water containing a heterogeneous assembly of unclad natural uranium fuel pins;

- a water-moderated, water-cooled assembly containing unclad natural uranium fuel pins (in reality, metal-clad pressure tubes and possibly a restraint grid would be required, but these were not included in the current scoping study);

- a non-nuclear-grade graphite-moderated, water-cooled assembly containing aluminum-clad natural uranium fuel pins, where non-nuclear-grade graphite is defined as having a density of $\sim 1.6-1.7 \mathrm{~g} / \mathrm{cm}^{3}$ with impurities equivalent to $5 \mathrm{ppm}$ natural boron; and

- a non-nuclear-grade graphite-moderated, $\mathrm{CO}_{2}$-cooled assembly containing aluminum-clad natural uranium fuel pins (in reality, magnesium alloy clad would be used instead of aluminum, but this should not make a significant neutronic difference for the purposes of this study).

\section{Results from Infinite Cell Calculations}

Infinite cell calculations were first performed for each assembly to determine the infinite multiplication factor, that is, $k_{\infty}$, and to obtain cell-weighted cross sections for further analysis using the CSAS1 control module in the SCALE 4.3 code system [28]. All neutronic calculations were performed at room temperature.

SCALE employs three functional models to perform the infinite cell calculations: BONAMI, NITAWL-II, and XSDRNPM. BONAMI and NITAWL-II treat resonance self-shielding, and XSDRNPM performs a one-dimensional discrete ordinates transport calculation to obtain the $k_{\infty}$ and the cell-weighted cross sections. Comparative calculations were carried out for 1-in.-diameter fuel pins in a small number of different cell pitches using most of the standard cross-section libraries in SCALE 4.3, and the resulting $k_{\infty}$ 's were compared against one another and with $k_{\infty}$ 's obtained using the point energy Monte Carlo code MCNP [29]. The immediate outcome of this comparison was that without going to more than 200 neutron energy groups, only the ANSL-V [30] 39 and 99 energy group neutron cross-section libraries (containing 29 thermal neutron energy groups) proved adequate 
for the present analysis. Since the ANSL-V 99 neutron energy group cross-section library provided more energy resolution at the higher neutron energies (i.e., above thermal energies) and most of the calculational effort is expended in the thermal energy range, it was chosen for use in the current analysis.

The calculated maximum $k_{\infty}$ 's and the fuel pin diameter and fuel cell pitch yielding the maximum $k_{\infty}$ for the heterogeneous water-moderated and graphite-moderated assemblies are given in Table 1 . Since the $k_{\infty}$ 's for both the homogeneous and heterogeneous uranyl nitrate assemblies were much less than 1.0 -that is, 0.59 and 0.83 , respectively-an extensive search for the combination of fuel pin diameter and fuel cell pitch that produces the largest $k_{\infty}$ was not carried out for the heterogeneous uranyl nitrate assembly. However, estimates of the ${ }^{238} \mathrm{U}$ neutron capture rates and therefore the ${ }^{239} \mathrm{Pu}$ production rates in these two types of assemblies were made.

In addition to optimal fuel pin diameter, cell pitch, and $k_{\infty}$ the infinite subcritical source multiplication defined by

$$
M_{\infty}=1 /\left(1-k_{\infty}\right)
$$

is also presented in Table 1 for the water-moderated and graphite-moderated assemblies. This is the subcritical source multiplication that would occur if an external neutron source having the same energy and spatial distribution as the fundamental mode fission source was introduced into the infinite cell model.

Table 1. Optimal infinite cell parameters for water-moderated and graphite-moderated assemblies

\begin{tabular}{|c|c|c|c|}
\hline \multirow[b]{2}{*}{ Parameter } & \multicolumn{3}{|c|}{ Assembly type } \\
\hline & $\begin{array}{c}\text { Graphite-moderated, } \\
\mathrm{CO}_{2} \text {-cooled }\end{array}$ & $\begin{array}{l}\text { Graphite-moderated, } \\
\text { water-cooled }\end{array}$ & $\begin{array}{l}\text { Water-moderated, } \\
\text { water-cooled }\end{array}$ \\
\hline Pin diameter (in.) & 1.375 & 1.5 & 0.875 \\
\hline Pitch (in.) & 8.1 & 8.1 & 1.27 \\
\hline$k_{\infty}$ & 0.99226 & 0.97859 & 0.97934 \\
\hline$M_{\infty}$ & 129.2 & 46.7 & 48.6 \\
\hline${ }^{238} \mathrm{U}$ capture rate ${ }^{a}$ & 0.405 & 0.407 & 0.438 \\
\hline
\end{tabular}

${ }^{a}$ Normalized to the subcritical fission source with unity integral value and with no external source.

\section{Scoping Results of Finite Assembly Calculations: Effects of Assembly Size and Source Neutron Energy}

In an actual finite assembly, the effective neutron multiplication factor or eigenvalue, that is, $k_{\text {eff }}$, would be lower than $k_{\infty}$. However, the subcritical source multiplication factor (or source-driven effective eigenvalue) given by 


$$
k_{\mathrm{scm}}=1-1 / M_{\mathrm{scm}}
$$

should be somewhat higher than $k_{\text {eff }}$ since the source would most likely be located in a region of high neutron importance (i.e., the center of the subcritical multiplying assembly). As the size of the finite assembly is increased and the value of $k_{\text {eff }}$ approaches that of $k_{\infty}, k_{\mathrm{scm}}$ should also approach $k_{\text {eff. }}$ This effect is illustrated in Table 2.

As noted above, the water-moderated assembly contained unclad fuel pins, whereas the graphite-moderated assemblies contained aluminum-clad fuel pins. In all of the calculations, the fuel pin clad thickness and coolant gap thickness were taken to be 0.9 and $1.5 \mathrm{~mm}$, respectively. In addition, the coolant channels in the graphite-moderated assemblies were lined with $1.6 \mathrm{~mm}$ of aluminum. These thicknesses are characteristic of the corresponding thicknesses in the Hanford graphite-moderated, water-cooled production reactors. Examination of the $M_{\infty}$ 's in Table 1 quickly reveals that the "optimized" $\mathrm{CO}_{2}$-cooled graphite-moderated assembly produces by a substantial amount the greatest number of fission neutrons per source neutron.

One-dimensional transport calculations were performed to obtain estimates of the ${ }^{238} U$ capture rate and therefore the ${ }^{239} \mathrm{Pu}$ production rates for finite sizes of each assembly. Spherical onedimensional models of each assembly were then constructed by determining the spherical radius $r$ which would yield the same geometric buckling as a cube or pile of size $L$; that is, $r=L /(3)^{1 / 2}$. The cell-weighted cross sections obtained from the infinite cell calculations together with homogenized nuclide number densities for the fuel, cladding, moderator, and coolant were employed in these calculations, and all of the calculations were carried out with the XSDRNPM code.

Table 2 illustrates the effect of size of the subcritical multiplying blanket on source multiplication and ${ }^{238} U$ captures. In Table 2, the ${ }^{238} U$ capture efficiency (UCE) is defined as the ${ }^{238} U$ captures per source neutron divided by the subcritical source multiplication. Table 3 and Figs. 1 through 3 illustrate the effect of the energy of the source neutron from the spallation target on source multiplication and ${ }^{238} \mathrm{U}$ captures.

The ${ }^{238} \mathrm{U}$ captures per $2.5-\mathrm{MeV}$ source neutron for each type of blanket assembly are presented in Table 4. The value of $2.5 \mathrm{MeV}$ was chosen as a fixed value of source neutron energy in this set of scoping calculations because it corresponds to the energy of neutrons emerging from deuteriumdeuterium (D-D) reactions used in light targets. Results are presented for three different sizes of blanket assemblies or "equivalent piles." The homogeneous uranyl nitrate assembly was analyzed only for an equivalent pile size of $8 \mathrm{ft}$. The heterogeneous uranyl assembly was analyzed for 8-, 10-, and 12-ft equivalent pile sizes, and the same ${ }^{238} \mathrm{U}$ capture was obtained. If the homogeneous assembly had been analyzed for a larger equivalent pile size, it is possible that the resulting ${ }^{238} \mathrm{U}$ capture per source neutron could be up to a factor of two higher. The results for the water-moderated, water-cooled assembly are given for both the 8- and 40 -ft equivalent pile sizes. The results for the two other blanket assemblies are given for a 40 -ft equivalent pile size since this was the largest size analyzed and approaches a pile of infinite size. 
Table 2. Subcritical source neutron multiplication and ${ }^{238} \mathrm{U}$ capture rate in a central-source-driven Hanford graphite-moderated, water-cooled lattice with $2.4-\mathrm{MeV}$ source neutrons

\begin{tabular}{cccccc}
\hline $\begin{array}{c}\text { Side length } \\
\text { of cubic } \\
\text { pile (ft) }\end{array}$ & $\begin{array}{c}\text { Subcritical } k_{\text {eff, }} \\
\text { multiplication } \\
\text { factor without } \\
\text { source }\end{array}$ & $\begin{array}{c}k_{\text {scm }} \text { source-driven } \\
\text { subcritical } \\
\text { multiplication } \\
\text { factor }\end{array}$ & $\begin{array}{c}\text { Subcritical source } \\
\text { multiplication, } \\
M_{\text {sem }}=1 /\left(1-k_{\text {scm }}\right)\end{array}$ & $\begin{array}{c}\text { Number of }{ }^{238} \mathrm{U} \\
\text { captures per } \\
\text { source neutron }\end{array}$ & $\begin{array}{c}{ }^{238} \mathrm{U} \text { capture } \\
\text { efficiency, } \\
\text { UCE }\end{array}$ \\
\hline 8 & 0.8079 & 0.8766 & 8.1035 & 3.0956 & 0.382 \\
12 & 0.8937 & 0.9317 & 14.6514 & 5.8953 & 0.402 \\
16 & 0.9266 & 0.9527 & 21.1519 & 8.6736 & 0.410 \\
20 & 0.9423 & 0.9626 & 26.7301 & 11.0569 & 0.414 \\
24 & 0.9507 & 0.9680 & 31.2481 & 12.9873 & 0.416 \\
28 & 0.9558 & 0.9681 & 31.3028 & 13.0107 & 0.416 \\
32 & 0.9589 & 0.9745 & 39.1589 & 16.3755 & 0.418 \\
40 & 0.9624 & 0.9745 & 39.1711 & 16.3811 & 0.418 \\
\hline
\end{tabular}

Table 3. Effect of neutron source energy on ${ }^{238} \mathrm{U}$ capture rate in an 8-ft (2.44-m) cubic pile with a central-source-driven Hanford graphite-moderated, water-cooled lattice (Note: Subcritical $k_{\text {eff }}=\mathbf{0 . 8 0 7 9}$ without source)

\begin{tabular}{ccccc}
\hline $\begin{array}{c}\text { Neutron source } \\
\text { energy (MeV) }\end{array}$ & $\begin{array}{c}k_{\text {scm, source-driven }} \text { multiplication } \\
\text { factor }\end{array}$ & $\begin{array}{c}\text { Subcritical source } \\
\text { multiplication, } \\
M_{\text {scm }}=1 /\left(1-k_{\text {scm }}\right)\end{array}$ & $\begin{array}{c}\text { Number of }{ }^{238} \mathrm{U} \\
\text { captures per } \\
\text { source neutron }\end{array}$ & $\begin{array}{c}{ }^{238} \text { U capture } \\
\text { efficiency, UCE }\end{array}$ \\
\hline 20 & 0.9205 & 12.5751 & 4.7717 & 0.379 \\
10 & 0.8978 & 9.7800 & 3.6755 & 0.376 \\
2.4 & 0.8766 & 8.1035 & 3.0956 & 0.382 \\
0.1 & 0.8712 & 7.7666 & 2.9875 & 0.385 \\
0.01 & 0.8739 & 7.9280 & 3.0428 & 0.384 \\
\hline
\end{tabular}




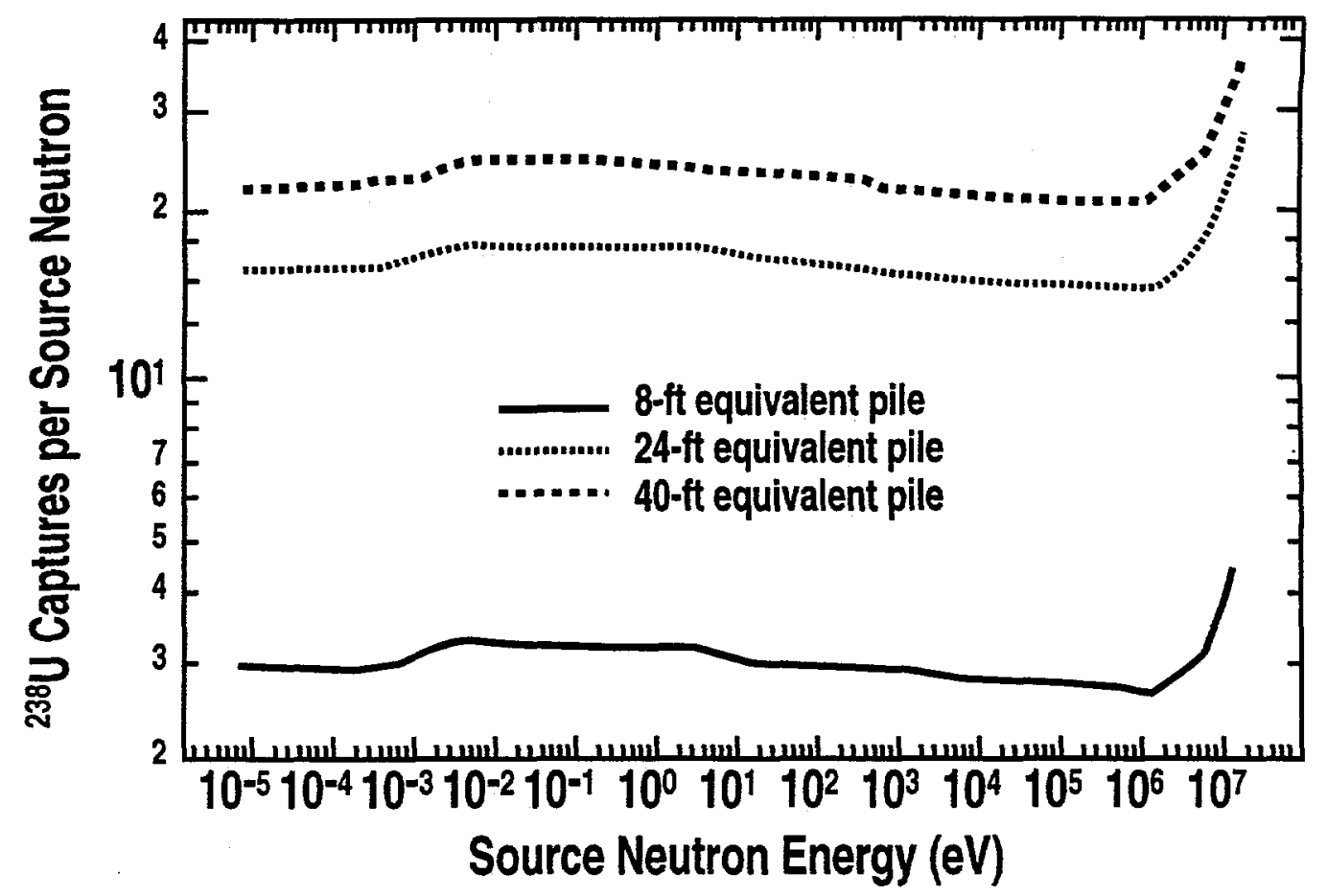

Fig. 1. Uranium-238 captures per source neutron in a graphite-moderated natural uranium lattice with $5 \mathrm{ppm}$ natural boron in graphite and a $1.5-\mathrm{mm} \mathrm{CO}$ gap between 0.9 and $1.6 \mathrm{~mm}$ of aluminum cladding.

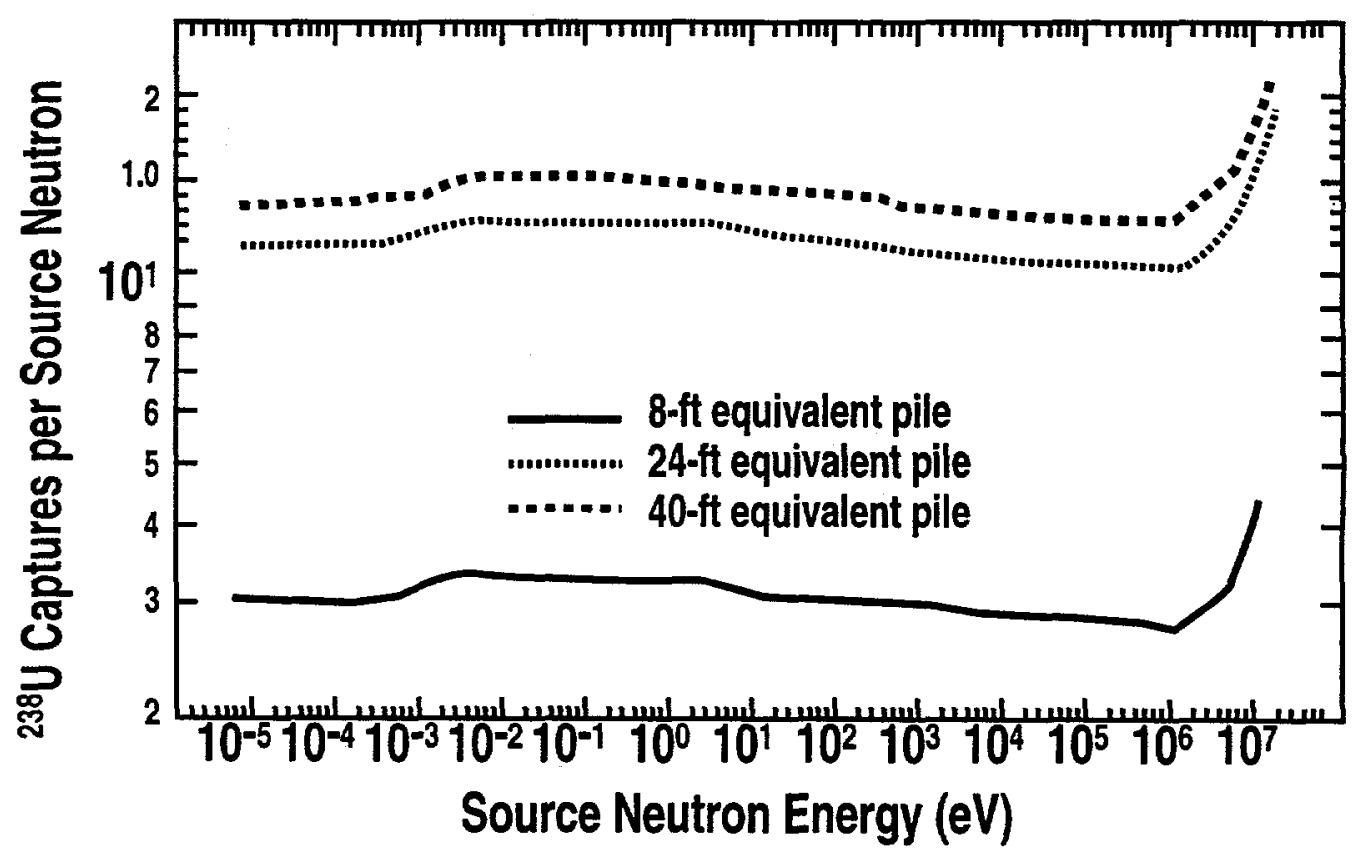

Fig. 2. Uranium-238 captures per source neutron in a graphite-moderated natural uranium lattice with $5 \mathrm{ppm}$ natural boron in graphite and a $1.5-\mathrm{mm} \mathrm{H}_{2} \mathrm{O}$ gap between 0.9 and $1.6 \mathrm{~mm}$ of aluminum cladding. 


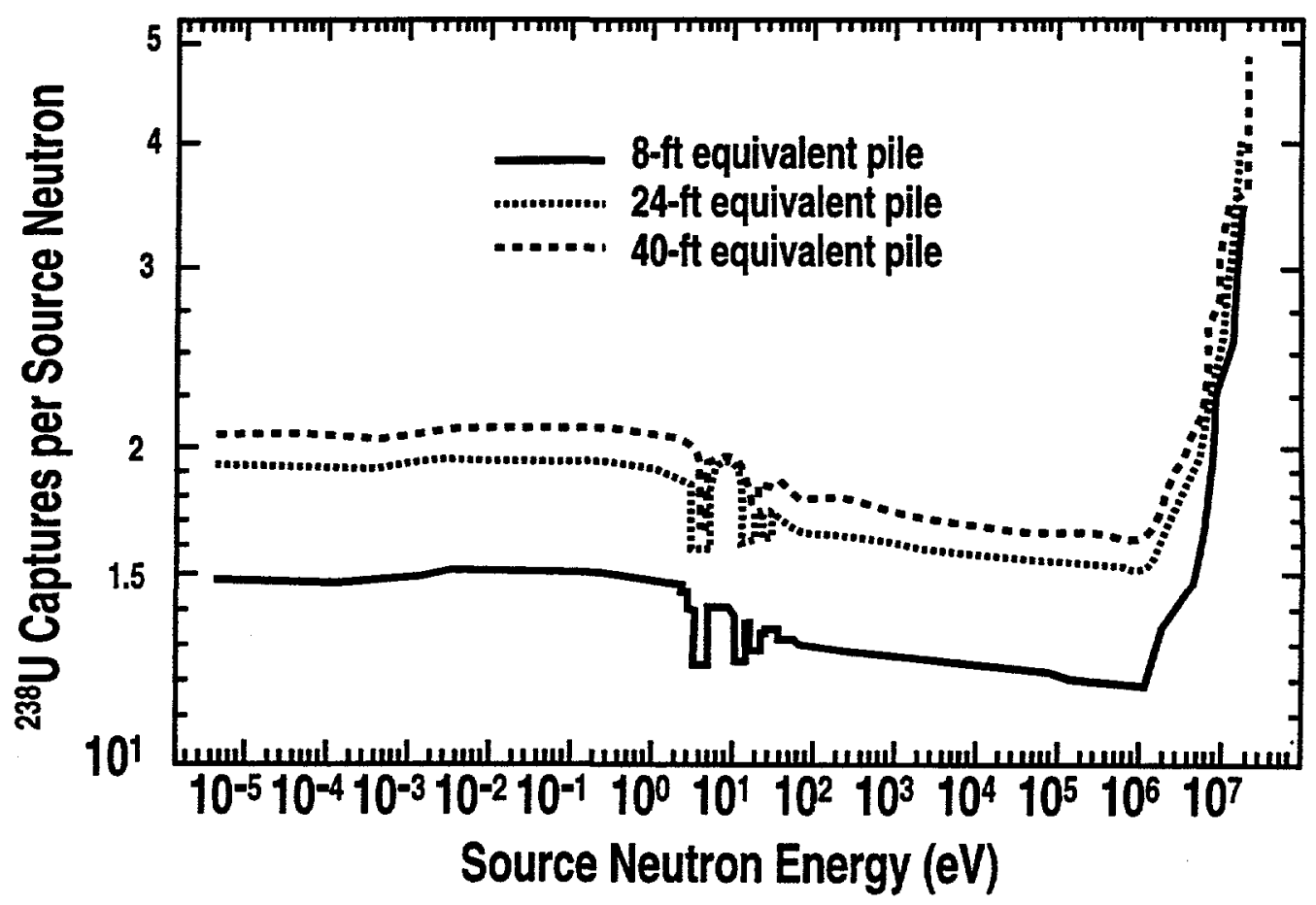

Fig. 3. Uranium-238 captures per source neutron in a water-moderated natural uranium lattice.

Table 4. Uranium-238 captures per 2.5-MeV source neutron in different blanket assemblies

\begin{tabular}{lcc}
\hline \multicolumn{1}{c}{ Blanket assembly type } & $\begin{array}{c}\text { Equivalent } \\
\text { pile size }(\mathrm{ft})\end{array}$ & $\begin{array}{c}{ }^{238} \mathrm{U} \text { captures per 2.5-MeV } \\
\text { source neutron }\end{array}$ \\
\hline Homogeneous uranyl nitrate & 8 & 0.7 \\
Heterogeneous uranyl nitrate & 12 & $3.0^{a}$ \\
Graphite-moderated, $\mathrm{CO}_{2}$-cooled & 40 & 23.0 \\
Graphite-moderated, water-cooled & 40 & 16.0 \\
Water-moderated, water-cooled & 8 & 13.0 \\
& 40 & 17.0 \\
\hline
\end{tabular}

${ }^{a}$ For the heterogeneous uranyl nitrate blanket assembly, two ${ }^{238} \mathrm{U}$ captures occurred in the fuel pins per source neutron, and one ${ }^{238} U$ capture occurred in uranyl nitrate per source neutron. 
As noted above, the ${ }^{238} \mathrm{U}$ captures per source neutron in Table 4 were found only for $2.5-\mathrm{MeV}$ neutrons. The results reported in Table 3 and Figs. 1 through 3 illustrate the effect of the energy of the source neutron from the spallation target on source multiplication and ${ }^{238} \mathrm{U}$ captures. To determine the ${ }^{238} \mathrm{U}$ captures per source neutron as a function of source neutron energy for each of the water-moderated and graphite-moderated blanket assemblies, adjoint one-dimensional spherical transport calculations were performed using the ${ }^{238} \mathrm{U}$ macroscopic capture cross section as the adjoint source. The calculated adjoint scalar flux within each energy group at the location of the neutron source-that is, at the center of each assembly-is the number of ${ }^{238} \mathrm{U}$ captures per source neutron produced within that energy group.

Using the adjoint-weighted method, the ${ }^{238} \mathrm{U}$ captures per source neutron for the graphitemoderated, $\mathrm{CO}_{2}$-cooled; graphite-moderated, water-cooled; and water-moderated, water-cooled blanket assemblies are illustrated in Figs.1, 2, and 3, respectively, for 8-, 16-, and 40-ft equivalent pile sizes. For the graphite-moderated assemblies, the results are fairly insensitive to source neutron energy except for energies above 4 or $5 \mathrm{MeV}$. Above these energies, the ${ }^{238} \mathrm{U}$ fission cross section approaches that of uranium-235 $\left({ }^{235} \mathrm{U}\right)$, and neutrons from fast fissions of ${ }^{238} \mathrm{U}$ contribute substantially to the subcritical source multiplication. This in part explains the historical interest in fast neutron breeding blankets, discussed in Section 3 . For the water-moderated assembly illustrated in Fig. 3 , there is a noticeable drop in the ${ }^{238} \mathrm{U}$ captures above 10 to $20 \mathrm{eV}$. This drop occurs because source neutrons born at this energy must negotiate the effects of resonance absorption in the ${ }^{238} \mathrm{U}$, which actually reduces the net ${ }^{238} \mathrm{U}$ captures because it reduces the thermal fission and subcritical multiplication in ${ }^{235} \mathrm{U}$. In the graphite-moderated assemblies, this drop does not occur because the cell pitch is much greater than the fuel pin diameter and source neutrons entering the system above 10 to $20 \mathrm{eV}$ have a good chance of scattering through the ${ }^{238} \mathrm{U}$ resonance range and causing fissions and multiplication. This is not the case in the water-moderated, water-cooled assemblies where the pitch is just slightly greater than the fuel pin diameter. In these assemblies, the neutrons entering the system have a high probability of entering the fuel and being absorbed in the ${ }^{238} \mathrm{U}$ before they can contribute through fission to the subcritical source multiplication.

Similar to the results given in Table 3, Fig. 4 illustrates the behavior of the UCE, which is the ratio of ${ }^{238} U$ captures per source neutron divided by the subcritical source multiplication, for the 8-, 24-, and 40-ft equivalent graphite-moderated, $\mathrm{CO}_{2}$-cooled blanket assemblies as a function of source neutron energy. Both Table 3 and Fig. 4 show that the UCE is essentially 0.36 at all source neutron energies for all equivalent pile sizes. The ${ }^{238} \mathrm{U}$ captures per source neutron energy is for all practical purposes simply a constant (the UCE) times the subcritical source multiplication $\left(M_{\mathrm{scm}}\right)$ at the same source neutron energy, as also evidenced by the behavior of the ${ }^{238} \mathrm{U}$ capture in the water-moderated blanket assembly.

\section{Results of Finite Assembly Calculations Using the Adjoint-Weighted Neutron Source from a Proton Accelerator-Driven Uranium Target}

To obtain estimates of the actual number of ${ }^{238} \mathrm{U}$ captures that might occur from acceleratorproduced neutrons, calculations for the neutron source spectrum were performed for $150-\mathrm{MeV}$ and $1-\mathrm{GeV}$ protons incident on a natural uranium target. These calculations were carried out using the high-energy transport code HETC [31] and MCNP. Since HETC only transports neutrons above $20 \mathrm{MeV}, \mathrm{MCNP}$ was needed to determine the energy spectra of the neutrons below $20 \mathrm{MeV}$ which 


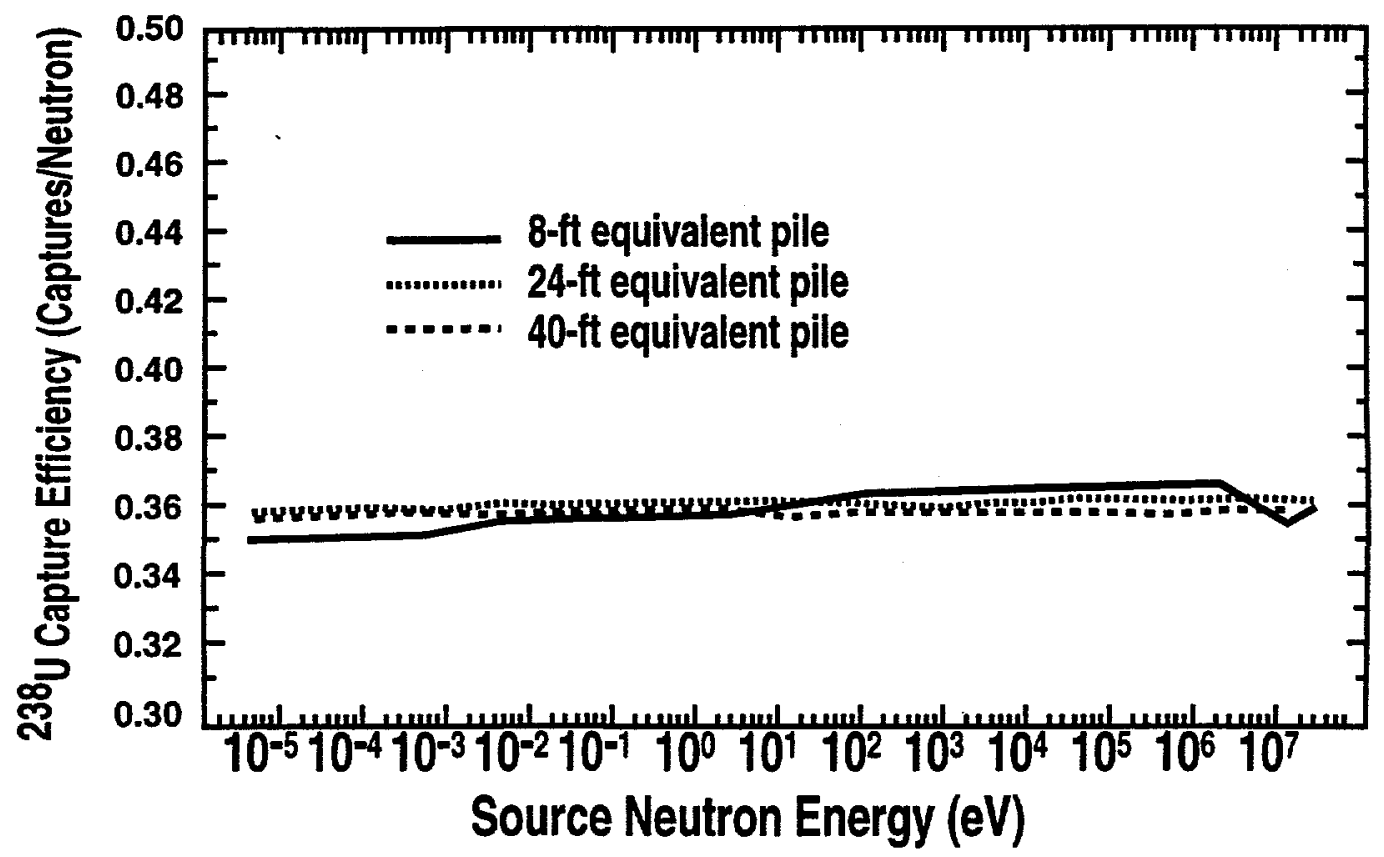

Fig. 4. Uranium-238 capture rate divided by subcritical source multiplication (5 ppm natural boron in graphite, $1.5-\mathrm{mm} \mathrm{CO}_{2}$ gap between 0.9 and $1.6 \mathrm{~mm}$ of aluminum cladding).

leak from the natural uranium target. The resulting neutron source leakage spectra from the target were then folded into the data in Figs. 1 through 3 to obtain the average number of ${ }^{238} \mathrm{U}$ captures per source neutron. The results from this folding are presented in Table 5.

The results in Table 5 indicate that the energy of the accelerator (i.e., proton energy) is unimportant in determining the number of ${ }^{238} \mathrm{U}$ captures per source neutron. Using the ${ }^{238} \mathrm{U}$ capture values in Table 5 for the uranyl nitrate assemblies and the values in Table 5 for the graphitemoderated and water-moderated assemblies allows the current and equivalent power required for $150-\mathrm{MeV}$ and $1-\mathrm{GeV}$ accelerators to produce $2 \mathrm{~kg} /$ year of ${ }^{239} \mathrm{Pu}$ to be estimated assuming ideal conditions (i.e., a ${ }^{238} \mathrm{U}$ capture rate of $1.6 \times 10^{17}$ captures per second). These requirements are summarized in Table 6.

The required beam currents and powers in Table 6 indicate that a single high-energy, state-ofthe-art accelerator could under ideal conditions produce $2 \mathrm{~kg} /$ year of ${ }^{239} \mathrm{Pu}$ with any of the thermal neutron blanket assemblies analyzed here. However, to produce $2 \mathrm{~kg} /$ year of ${ }^{239} \mathrm{Pu}$ with off-the-shelf, low-technology, 150-MeV accelerators, 4 to 18 such units would be required. 
Table 5. Average ${ }^{238} \mathrm{U}$ captures per source neutron in three blanket assemblies for $150-\mathrm{MeV}$ and 1-GeV protons incident on a natural uranium target

\begin{tabular}{ccccccc}
\hline & \multicolumn{6}{c}{ Blanket assembly type } \\
\cline { 2 - 7 } $\begin{array}{c}\text { Equivalent pile } \\
\text { size (ft) }\end{array}$ & $\begin{array}{c}\text { Graphite-moderated, } \\
\mathrm{CO}_{2} \text {-cooled }\end{array}$ & $\begin{array}{c}\text { Graphite-moderated, } \\
\text { water-cooled }\end{array}$ & \multicolumn{2}{c}{$\begin{array}{c}\text { Water-moderated, } \\
\text { water-cooled }\end{array}$} \\
\cline { 2 - 7 } & $150 \mathrm{MeV}$ & $1 \mathrm{GeV}$ & $150 \mathrm{MeV}$ & $1 \mathrm{GeV}$ & $150 \mathrm{MeV}$ & $1 \mathrm{GeV}$ \\
\hline 8 & 2.80 & 2.81 & 2.87 & 2.88 & 13.82 & 13.86 \\
24 & 15.78 & 15.77 & 11.41 & 11.40 & 17.73 & 17.78 \\
40 & 22.38 & 22.37 & 13.53 & 13.52 & 19.13 & 19.18 \\
\hline
\end{tabular}

Table 6. Minimum estimates of accelerator current and beam power requirements to produce $2 \mathrm{~kg} /$ year of ${ }^{239} \mathrm{Pu}$

\begin{tabular}{cccccc}
\hline & \multicolumn{5}{c}{ Blanket assembly type } \\
\cline { 2 - 6 } & $\begin{array}{c}\text { Homogeneous } \\
\text { uranyl nitrate } \\
\text { (8-ft equiv. pile) }\end{array}$ & $\begin{array}{c}\text { Heterogeneous } \\
\text { uranyl nitrate } \\
(12-\mathrm{ft} \text { equiv. pile) }\end{array}$ & $\begin{array}{c}\text { Graphite-moderated, } \\
\mathrm{CO}_{2} \text {-cooled } \\
\text { (40-ft equiv. pile) }\end{array}$ & $\begin{array}{c}\text { Graphite-moderated, } \\
\text { water-cooled } \\
\text { (40-ft equiv. pile) }\end{array}$ & $\begin{array}{c}\text { Water-moderated, } \\
\text { water-cooled } \\
\text { (8-140-ft equiv. pile) }\end{array}$ \\
\hline $\begin{array}{c}\text { (4) } \\
150 \mathrm{MeV}\end{array}$ & & & & \\
Current & $36.6 \mathrm{~mA}$ & $8.5 \mathrm{~mA}$ & $1.1 \mathrm{~mA}$ & $1.9 \mathrm{~mA}$ & $1.8 / 1.3 \mathrm{~mA}$ \\
Power & $5.49 \mathrm{MW}$ & $1.28 \mathrm{MW}$ & $0.16 \mathrm{MW}$ & $0.29 \mathrm{MW}$ & $0.28 / 0.2 \mathrm{MW}$ \\
$1 \mathrm{GeV}$ & & & & & \\
Current & $0.91 \mathrm{~mA}$ & $0.21 \mathrm{~mA}$ & $14 \mu \mathrm{A}$ & $24 \mu \mathrm{A}$ & $46 / 33 \mu \mathrm{A}$ \\
Power & $0.91 \mathrm{MW}$ & $0.21 \mathrm{MW}$ & $14 \mathrm{~kW}$ & $24 \mathrm{~kW}$ & $46 / 33 \mathrm{~kW}$ \\
\hline
\end{tabular}

For practical considerations of engineering design, the question must be posed as to whether the larger equivalent piles are realistic. Table 7 presents the masses of natural uranium metal in each size of equivalent pile considered in the study.

A typical large-sized graphite-moderated, gas-cooled production reactor such as France's G2 and G3 used a metallic fuel loading of about $120 \mathrm{MT}$ [32]. The rated thermal power level of each of the $\mathrm{G} 2$ and $\mathrm{G} 3$ reactors was $200 \mathrm{MW}$ so that the average power density was $\sim 1.7 \mathrm{MW} / \mathrm{MT}$. The graphite-moderated, water-cooled Hanford N-Reactor held $365 \mathrm{MT}$ of metallic fuel, and the loadings in the older graphite-moderated, water-cooled Hanford piles ranged from 150 to $200 \mathrm{MT}$ [33]. The Hanford N-Reactor had a rated thermal power level of $4000 \mathrm{MW}$ so that the average power density was $\sim 11 \mathrm{MW} / \mathrm{MT}$. The largest modern light water reactors use enriched uranium oxide as fuel but have an equivalent metallic loading of about $100 \mathrm{MT}$ or less. The results presented in Table 7 would indicate that a cubic pile with a side length of $8.5-9.8 \mathrm{~m}(28-32 \mathrm{ft})$ is about the largest practical size for the graphite-moderated systems and that a cubic pile with a side length of about $2.44 \mathrm{~m}(8 \mathrm{ft})$ is most likely the largest practical size for the light-water-moderated system. 
Table 7. Mass in metric tons of natural uranium metal fuel required in graphitemoderated and water-moderated assemblies as a function of pile size

\begin{tabular}{cccc}
\hline $\begin{array}{c}\text { Side length of } \\
\text { cubic pile [m (ft)] }\end{array}$ & $\begin{array}{c}\text { Graphite-moderated, } \\
\mathrm{CO}_{2} \text {-cooled }\end{array}$ & $\begin{array}{c}\text { Graphite-moderated, } \\
\text { water-cooled }\end{array}$ & $\begin{array}{c}\text { Water-moderated, } \\
\text { water-cooled }\end{array}$ \\
\hline $2.44(8)$ & 10 & 11 & 102 \\
$3.66(12)$ & 21 & 25 & 345 \\
$4.88(16)$ & 50 & 59 & 817 \\
$6.096(20)$ & 97 & 115 & 1,596 \\
$7.315(24)$ & 168 & 199 & 2,758 \\
$8.534(28)$ & 266 & 316 & 4,380 \\
$9.754(32)$ & 397 & 473 & 6,539 \\
$12.192(40)$ & 775 & 923 & 12,771 \\
\hline
\end{tabular}

However, for the purpose of producing $2 \mathrm{~kg} / \mathrm{year}$ of plutonium, a potential proliferator would weigh the option of building a small critical reactor versus that of building an accelerator-driven subcritical reactor in which the power density and production capacity would be much lower at least for the low-power accelerator beam. Table 8 illustrates the relative core sizes and masses of natural uranium fuel for several small reactors that have been built, have characteristics similar to larger production reactors, and would likely serve as analytical benchmarks or engineering prototypes for a potential proliferator. There are no light-water-moderated natural uranium critical experiments or reactors because criticality is not possible with light water moderation and natural uranium.

Considering the likely engineering limitations on constructing large thermal piles and the likely limitations on access to natural uranium, the most realistic estimates of minimum accelerator currents and beam powers would appear to be based on assuming that the minimum mass of natural uranium in the pile should be greater than $25 \mathrm{MT}$ so as to be comparable to the smallest-sized reactor alternative. Results of analyses performed assuming a subcritical pile loaded with 25 MT of natural uranium are presented in Table 9. 
Table 8. Parameters for selected small reactors

\begin{tabular}{|c|c|c|c|c|c|c|c|}
\hline Reactor designation & $\begin{array}{c}\text { Moderator / } \\
\text { coolant }\end{array}$ & $\begin{array}{c}\text { Core shape / } \\
\text { dimensions ( } \mathrm{ft})\end{array}$ & $\begin{array}{l}\text { Cold critical } \\
\text { fuel mass } \\
\text { (MT) }\end{array}$ & $\begin{array}{l}\text { At-power } \\
\text { fuel mass } \\
\text { (MT) }\end{array}$ & $\begin{array}{c}\text { Power (MW) / } \\
\text { power density } \\
\text { (MW/MT) }\end{array}$ & $\begin{array}{l}\text { Fuel and coolant } \\
\text { temperatures }\left({ }^{\circ} \mathrm{C}\right)\end{array}$ & $\begin{array}{c}\text { At-power reactivity } \\
\text { defects, } \Delta k\end{array}$ \\
\hline $\begin{array}{l}\text { NRX (Chalk River, } \\
\text { Ontario, Canada) }\end{array}$ & $\mathrm{D}_{2} \mathrm{O} / \mathrm{H}_{2} \mathrm{O}$ & $\begin{array}{l}\text { Cylinder } \\
D=8.88 \\
H=10.45\end{array}$ & 5.85 & 9.25 & $40 / 4.32$ & $\begin{array}{l}\text { Max fuel }=668 \\
\text { T-in }=10 \\
\text { T-out }=50\end{array}$ & Total: -0.027 \\
\hline CP-1 (Chicago Pile) & Graphite / air & $\begin{array}{l}\text { Oblate sphere } \\
D_{r}=12.9 \\
D_{z}=10.28\end{array}$ & 5.63 & $\begin{array}{c}\text { Not } \\
\text { applicable }\end{array}$ & $0.0 / 0.0$ & Not applicable & Not applicable \\
\hline $\begin{array}{l}\text { Hanford } 305 \text { Test } \\
\text { Reactor }\end{array}$ & Graphite / air & $\begin{array}{l}\text { Elongated cube / } \\
12 \times 12 \times 15.5\end{array}$ & 16.38 & 17.18 & $3 \times 10 \quad / \sim 0$ & Not applicable & Nớ applicable \\
\hline $\begin{array}{l}\text { X-10 Reactor (Oak } \\
\text { Ridge, Tennessee) }\end{array}$ & Graphite / air & $\begin{array}{l}\text { Cube / } \\
\mathrm{L}=18.26\end{array}$ & 27.4 & 48 & $3.5 / 0.073$ & $\begin{array}{l}\text { Max clad }=270 \\
\text { T-in }=15 \\
\text { T-out }=77\end{array}$ & $\begin{array}{l}\text { Temp: }-0.004 \\
\text { Xe: }-0.002\end{array}$ \\
\hline $\begin{array}{l}\text { Belgian BR-1 (Mol, } \\
\text { Belgium) }\end{array}$ & Graphite / air & $\begin{array}{l}\text { Cylinder } / \\
\mathrm{D}=15.97 \\
\mathrm{H}=22.16\end{array}$ & 15.2 & 23.9 & $4 / 0.167$ & $\begin{array}{l}\text { Max fuel }=260 \\
\text { T-in }=15 \\
\text { T-out }=75\end{array}$ & $\begin{array}{l}\text { Temp: }-0.0058 \\
\text { Xe, Sm: }-0.0037\end{array}$ \\
\hline $\begin{array}{l}\text { BEPO (Harwell, } \\
\text { U.K.) }\end{array}$ & Graphite / air & $\begin{array}{l}\text { Cylinder } / \\
D=20.29 \\
H=20.29\end{array}$ & 28.45 & 40.64 & $6.5 / 0.148$ & $\begin{array}{l}\text { Max fuel }=250 \\
\text { T-in }=\sim 20 \\
\text { T-out }=95\end{array}$ & $\begin{array}{l}\text { Temp: }-0.003 \\
\text { Xe, Sm: }-0.0033\end{array}$ \\
\hline $\begin{array}{l}\text { G1 (Marcoule, } \\
\text { France) }\end{array}$ & Graphite / air & $\begin{array}{l}\text {-Cylinder } / \\
D=27.45 \\
H=27.94\end{array}$ & 24.3 & 100 & $38 / 0.38$ & $\begin{array}{l}\text { Max fuel }=400 \\
\mathrm{~T} \text {-in }=18 \\
\mathrm{~T} \text {-out }=135\end{array}$ & $\begin{array}{l}\text { Temp: }-0.0065 \\
\text { Xe, Sm: }-0.0085 \\
\text { Burn-up: negligible }\end{array}$ \\
\hline $\begin{array}{l}\text { Calder Hall Reactors } \\
\text { (Sellafield, U.K.) }\end{array}$ & Graphite / $\mathrm{CO}_{2}$ & $\begin{array}{l}\text { Cylinder } / \\
D=31.44 \\
H=21.29\end{array}$ & 31 & 127 & $180 / 1.42$ & $\begin{array}{l}\text { Nom clad }=418 \\
\text { T-in }=140 \\
\text { T-out }=340\end{array}$ & $\begin{array}{l}\text { Temp: }-0.014 \\
\text { Xe, Sm: }-0.026 \\
\text { Pu: }+0.021 \text { at } 1000 \\
\text { MWd/MT }\end{array}$ \\
\hline
\end{tabular}

Source: Refs. 32, 34, 35, and 36. 
Table 9. Estimates of minimum accelerator current and beam power requirements to produce $2 \mathrm{~kg} /$ year of ${ }^{239} \mathrm{Pu}$ in a subcritical pile loaded with 25 metric tons of natural uranium (no accounting for feedbacks)

\begin{tabular}{cccc}
\hline & \multicolumn{3}{c}{ Blanket assembly type } \\
\cline { 2 - 4 } & $\begin{array}{c}\text { Graphite-moderated, } \\
\mathrm{CO}_{2} \text {-cooled } \\
(12.7-\mathrm{ft} \text { equiv. pile) }\end{array}$ & $\begin{array}{c}\text { Graphite-moderated, } \\
\text { water-cooled } \\
\text { (12-ft equiv. pile) }\end{array}$ & $\begin{array}{c}\text { Water-moderated, } \\
\text { water-cooled } \\
\text { (5-ft equiv. pile) }\end{array}$ \\
\hline $150 \mathrm{MeV}$ & & & \\
Current & $3.7 \mathrm{~mA}$ & $4.44 \mathrm{~mA}$ & $2.3 \mathrm{~mA}$ \\
Power & $0.56 \mathrm{MW}$ & $0.67 \mathrm{MW}$ & $0.35 \mathrm{MW}$ \\
& & & \\
$1 \mathrm{GeV}$ & & & \\
Current & $94.1 \mu \mathrm{A}$ & $113.2 \mu \mathrm{A}$ & $58.5 \mu \mathrm{A}$ \\
Power & $94.1 \mathrm{~kW}$ & $113.2 \mathrm{~kW}$ & $58.5 \mathrm{~kW}$ \\
\hline
\end{tabular}

Comparing the results in Tables 6 and 9 indicates that the effect on the beam requirements due to limiting the size of the production blanket to that dictated by engineering experience is largest for the graphite-moderated, $\mathrm{CO}_{2}$-cooled pile (up to a factor of 6.7 between side lengths of $40 \mathrm{ft}$ and $12.7 \mathrm{ft}$ ) and least for the water-moderated, water-cooled pile (only a factor of 1.7-1.8 between side lengths of $40 \mathrm{ft}$ and $5 \mathrm{ft}$ ). Most significant is that the water-moderated, water-cooled lattice is both the smallest and most efficient at a loading of $25 \mathrm{MT}$ of natural uranium. The effects of size reduction can be explained as follows:

- Both of the graphite lattices have relatively widely spaced fuel pins (as shown in Table 1) and large thermal neutron migration areas, so smaller pile sizes tend to increase neutron losses due to leakage from the pile. The effects are more pronounced in the $\mathrm{CO}_{2}$-cooled lattice where the larger, voided cooling holes reduce the effective density of the graphite.

- Water is a more effective neutron moderator, and the fuel pins in the water-moderated lattice are much more tightly packed (as shown in Table 1). Therefore, neutron leakage from the watermoderated lattice tends to be much smaller overall than in the graphite-moderated lattices as the pile sizes decrease. At larger pile sizes, the larger thermal neutron capture cross section of hydrogen in the water is a more significant effect than that of the $5 \mathrm{ppm}$ of natural boron simulated in the calculations of the graphite lattices.

The results indicate that unless only a very low power accelerator is obtainable, there is no need for a potential proliferator to invest in graphite and the efforts that it entails to produce or to risk exposure while attempting to procure large quantities of an export-controlled material. However, other significant effects must be addressed, as discussed below. 


\section{Other Effects on Minimum Beam Power Requirements}

Four effects that were not treated in the ORNL study reported above may alter the accelerator beam current and power requirements from those listed in Table 7. The four effects are as follows:

- Fission product buildup (particularly, equilibrium xenon concentration that produces a near-term significant negative reactivity effect).

- Temperature-dependent effects such as change in the graphite thermal neutron scattering with increased temperature (tends to be a positive reactivity effect), moderator density changes in the water-moderated lattices (tends to be a negative reactivity effect), and ${ }^{238} U$ resonance Doppler broadening in all the lattices due to blanket structural heating (tends to be a negative reactivity effect).

- The changes in the heavy metal isotopics due to ${ }^{235} \mathrm{U}$ burn-up (tends to be a negative reactivity effect) and ${ }^{239} \mathrm{Pu}$ burn-in (tends to be a positive reactivity effect).

- The realistic structural requirements for the water-moderated assembly in terms of cladding, pressure tubes, and grid support provided inherently by the graphite in the other lattices.

The burn-in of ${ }^{239} \mathrm{Pu}$ tends to increase subcritical source multiplication through fission contributions. On the other hand, fission product buildup, changes in moderator density, and ${ }^{238} \mathrm{U}$ resonance Doppler broadening generally tend to reduce subcritical source multiplication. Increasing graphite temperature increases the average energy of the thermal neutrons and thereby typically increases subcritical source multiplication by reducing the losses of thermal neutrons to impurities in the graphite that tend to have neutron absorption properties that vary inversely with neutron velocity. In an actual production facility, blanket rod change-out would have to be more frequent in the high power regions to ensure a high enrichment of ${ }^{239} \mathrm{Pu}$, and it is not believed that the effect of ${ }^{239} \mathrm{Pu}$ burn-in would be very great over either a short irradiation period or a low exposure (i.e., exposure at a low power density). On the other hand, fission product buildup and ${ }^{238} \mathrm{U}$ resonance broadening could possibly produce a notable decrease in the ${ }^{238} U$ captures per source neutron. Similarly accounting for the actual structural-materials requirements for the water-moderated lattice can be expected to decrease ${ }^{238} \mathrm{U}$ captures per source neutron, but this can be mitigated partially by reoptimization of the lattice design and careful materials selection (such as use of aluminum at lower temperatures or zirconium alloys at higher temperatures). Although significant additional calculational effort would be needed to quantify the actual change in the lattices studied above, other practical considerations can be used to bound some of these effects to a first-order approximation.

It is noted that the rule-of-thumb for thermal neutron reactors is that the production rate of plutonium is about $0.25 \mathrm{~kg}$ per megawatt-year of thermal energy production. This value correlates to an "effective" ${ }^{238} \mathrm{U}$ capture rate of about $0.26{ }^{238} \mathrm{U}$ captures per source neutron, which in the case of a reactor is only fission source neutrons. But, in general, the fission-source-normalized ${ }^{238} \mathrm{U}$ capture rates and the total-source-normalized UCEs for the lattices considered in the ORNL study are about 0.4 .

\section{Comparison with the ANL Study}

A brief subsequent study was performed incorporating several of the effects discussed above in order to provide a basis for comparison to the ANL study reported in the next section. In this latter brief study, infinite cell calculations were performed for VVER-1000 type fuel elements moderated in light water. In these calculations, the $4.4 \%$ enriched uranium oxide of the VVER-1000 fuel was 
replaced with natural uranium oxide. Key parameters for the blanket assembly are (1) a blanket fuel pellet radius of $0.386 \mathrm{~cm},(2)$ an outer zirconium clad radius of $0.4582 \mathrm{~cm}$, and (3) a triangular blanket rod pitch of $1.27 \mathrm{~cm}$. Separate cases by different analysts were run using WIMS and SCALE. At room temperature $\left(20^{\circ} \mathrm{C}\right)$, WIMS predicts a $k_{\infty}$ of $0.875\left(M_{\infty}=8.0\right)$, whereas SCALE predicts a $k_{\infty}$ of $0.879\left(M_{\infty}=8.26\right)$. When compared with the values of $k_{\infty}$ and $M_{\infty}$ presented in Table 1 for the cases studied by ORNL, it is evident that the infinite subcritical multiplication of the VVER-1000 lattice is about a factor of five to six lower than that of either the graphite-moderated, water-cooled assembly or the water-moderated, water-cooled assembly. This ratio would be expected to be preserved for the largest lattices analyzed by ANL, and this appears to be the case as evidenced by the difference in estimated minimum beam power requirements between the ORNL and ANL results.

In addition, using the heavy-metal isotopics depletion option in WIMS that includes fission products, the ORNL WIMS model of the VVER-1000 infinite cell was used to simulate operation at a power density of $3 \mathrm{MW}$ per metric ton of natural uranium. This is compared to the ORNL studies where the average power density is inferred to be less than $0.4 \mathrm{MW}$ per metric ton of natural uranium. At a fuel temperature of $200^{\circ} \mathrm{C}$ and a moderator coolant temperature of $20^{\circ} \mathrm{C}$ (i.e., assuming conditions closest to the warm fuel case as assumed in the ANL study), the initial $k_{\infty}$ before burn-up was predicted to be $0.8619\left(M_{\infty}=7.24\right)$. This result indicates that for a 0.013 incremental decrease in the value of $k_{\infty}$, the infinite subcritical multiplication decreases about $10 \%$ for the higher fuel temperature conditions assumed for this case. After simulating 30 days of depletion, $k_{\infty}$ was calculated to be 0.8572 . After 90 days of simulated depletion, $k_{\infty}$ was predicted to be 0.8688 . Therefore, almost 90 days of exposure is needed for $k_{\infty}$ to exceed its initial value at the assumed power density. After 360 days of simulated operation without changing the blanket elements, predicted $k_{\infty}$ rises to 0.9003 due to plutonium burn-in.

Replacing the VVER-1000 blanket rods after each 30 days at $3 \mathrm{MW}$ per metric ton of natural uranium results in a predicted plutonium production of $1.31 \mathrm{~kg} /$ year per metric ton of natural uranium with the discharged ${ }^{239} \mathrm{Pu}$ content at $98.4 \%$. This equates to $0.44 \mathrm{~kg}$ of plutonium per megawatt-year compared to the reactor rule-of-thumb of 0.25 quoted previously. The same case in WIMS was also executed at a power density of $10 \mathrm{MW}$ per metric ton of natural uranium. Again, simulating the replacement of the blanket rods every 30 days results in a predicted plutonium production of $4.28 \mathrm{~kg} / \mathrm{year}$ per metric ton of natural uranium. This equates to $0.42 \mathrm{~kg}$ of plutonium per megawatt-year compared to the reactor rule-of-thumb of 0.25 . Both results imply a UCE of about 0.45 , which compares favorably with the values of the infinite lattice, fission-source-normalized ${ }^{238} U$ capture rates $(0.405$ to 0.438$)$ shown in Table 1 .

The differences in the ORNL and ANL results are that (1) ANL selected a lattice that is not optimally moderated (i.e., a factor of five or so lower subcritical source multiplication) and (2) ANL assumed conditions of powered operation that yield a much larger temperature-dependent reactivity effect that further contributes to reducing subcritical source multiplication. ANL thus predicts much higher requirements for beam power to produce $2 \mathrm{~kg} /$ year of plutonium.

\subsection{ANL Technical Investigations}

Technical analyses at ANL considered the case where a proliferator acquires a stock of natural uranium oxide, together with the ability to produce typical pressurized water reactor (PWR) fuel assemblies in simplified form. Zirconium would be preferred (and was used in the calculation for worst-case results), but aluminum could be used with little penalty for low-burnup, low-temperature applications. In fact, using aluminum cladding with metallic uranium fuel would be preferred for 
simplicity of fabrication and reprocessing. Both the United States and Russia used graphitemoderated reactors with aluminum-clad uranium metal fuel, slightly enriched, for their plutonium production. A proliferator may decide not to acquire a large mass of graphite or heavy water if he finds that light water can be effective enough. Both of those moderators are export-controlled. Base calculations considered natural uranium only. Later, the use of slightly enriched uranium and optimization of the lattice pitch were investigated. To begin, it was assumed that the proliferator was not interested in a substantial design effort to optimize the neutronic performance of the fuel lattice. A proliferator simply would copy typical PWR practice (i.e., use of uranium oxide fuel) from the public domain. Optimization of the simple lattice chosen for this study required minimizing the lattice pitch in order to maximize the fuel reactivity and neutron multiplication. Since the coolant volume fraction was then reduced to the geometrical minimum, it was concluded that heat removal requirements would limit the practical reduction of lattice pitch. It was determined that plutonium production rates could increase by a factor of about three for fuel discharged at $1000 \mathrm{MWd} / \mathrm{MT}$ by reducing the lattice pitch to the minimum, provided that the heat could be removed.

The codes and methods used were LEOPARD, for neutron cross sections in four groups (sufficient for typical PWR calculations); and VENTURE, for neutron flux calculations given a fixed source of neutrons located at core center. In this case, the "core" is not a critical reactor, and it need not have any control systems. It simply must be cooled commensurate with its power capability when driven by an intense spallation neutron source. All of the spallation neutrons were assumed to begin their life in group 1 of the cross section set (between $10 \mathrm{MeV}$ and $0.821 \mathrm{MeV}$ ). One could improve upon and verify this assumption in the future by using the WIMS code to create a cross section set with more energy groups in this range. Fuel was exposed to less than $1 \mathrm{MWd} / \mathrm{kg}$ in order to limit the buildup of higher isotopes of plutonium (i.e., to keep the product mostly ${ }^{239} \mathrm{Pu}$ ). VENTURE performed a burnup calculation, using cross sections generated for high-power, hightemperature conditions. This introduced fission products and nonlinearities in isotopic compositions, thereby achieving a more realistic plutonium production rate estimate than would be achieved from projecting zero-burnup reaction rates.

Results for plutonium production rate versus neutron source strength were obtained for three subcritical core loadings, that is, 1,10 , and $70 \mathrm{MT}$ of natural uranium. It was assumed that the system operates at $100 \%$ capacity factor. The $1.1 \%$ enriched core has a $k_{\text {eff }}$ of about 0.847 for the 1 MT loading and 0.977 for the 10-MT loading. It goes critical for the 70-MT loading $\left(k_{\text {eff }}=1.014\right)$. The results appear to be affected little if the cladding is aluminum or if the operating conditions are not at high temperature and pressure.

No assumptions were made about the nature of the spallation neutron target. It was simply replaced by a "point" neutron source at core center. For ease of verification, the new results are not in triangular-z geometry, but in spherical geometry. This is a conservative assumption in that the neutron leakage is minimized and the multiplication is maximized over that of a more realistically engineered core in the shape of a cylinder or a hexagon.

Engineering considerations about local power peaking near the target and about heat removal from the target must be dealt with to operate subcritical cores at high power. One could expect to reduce power peaking effects near the central target (which is preferred, because the neutrons have less chance to leak from the system) by having multiple targets, either beam-switched or from multiple smaller accelerators.

The target neutron source strength needed for an annual production rate of $2 \mathrm{~kg}$ at $100 \%$ capacity factor is shown in Table 10 . If the natural uranium fuel is enriched to $1.1 \%$, the source strength is reduced by more than $40 \%$, to $5.0 \times 10^{16}$ neutrons/second. Similarly, the 10 -MT loading when enriched to $1.1 \%$ cuts the source by almost a factor of 10 , to $5.5 \times 10^{15}$ neutrons/second. 
Table 10. Target neutron source strength

\begin{tabular}{cc}
\hline $\begin{array}{c}\text { Natural uranium loading } \\
\text { (metric tons) }\end{array}$ & $\begin{array}{c}\text { Source strength for } 2 \mathrm{~kg} \mathrm{Pu} / \text { year } \\
\text { (neutrons/second) }\end{array}$ \\
\hline 1 & $9.0 \times 10^{16}$ \\
10 & $5.0 \times 10^{16}$ \\
70 & $4.5 \times 10^{16}$ \\
\hline
\end{tabular}

\section{Proton Accelerator Power and Accelerator Facilities}

ANL calculated the power of a proton accelerator required to produce $2 \mathrm{~kg} / \mathrm{year}$ of plutonium. The calculations used the revised neutronics results for the effect of a spallation neutron source on typical LWR natural uranium fuel in a subcritical assembly. ANL considered 1-, 10-, and 70-MT uranium loadings with the corresponding neutron yields of $8.6 \times 10^{16}, 5.2 \times 10^{16}$, and $4.5 \times 10^{16}$, necessary for the annual $2 \mathrm{~kg}$ of plutonium production. Los Alamos LAHET-MCNP neutron production calculations were used to compute the proton current required to achieve these threshold yields for two types of targets: solid uranium and liquid lead. ANL's results are shown graphically in Fig. 5.

Table 11 shows selected data for the points in Fig. 5. It gives the number of neutrons per spallation proton of usable leakage (the Los Alamos calculations using the LAHET-MCNP code) and the corresponding accelerator power as a function of proton energy.

Tables 12 and 13 were obtained under three different assumptions for the operating conditions, as follows:

- hot: fuel pellets at $530^{\circ} \mathrm{C}$, coolant at $285^{\circ} \mathrm{C}\left(545^{\circ} \mathrm{F}\right)$ and 124 bars (1800 psi) (normal at-power PWR conditions);

- warm: fuel pellets at $300^{\circ} \mathrm{C}$, coolant at $150^{\circ} \mathrm{C}$ and 6.9 bars $(100 \mathrm{psi})$; and

- cold: fuel pellets at $20^{\circ} \mathrm{C}$, coolant at $20^{\circ} \mathrm{C}$ and 1.4 bar (very low power operation). 


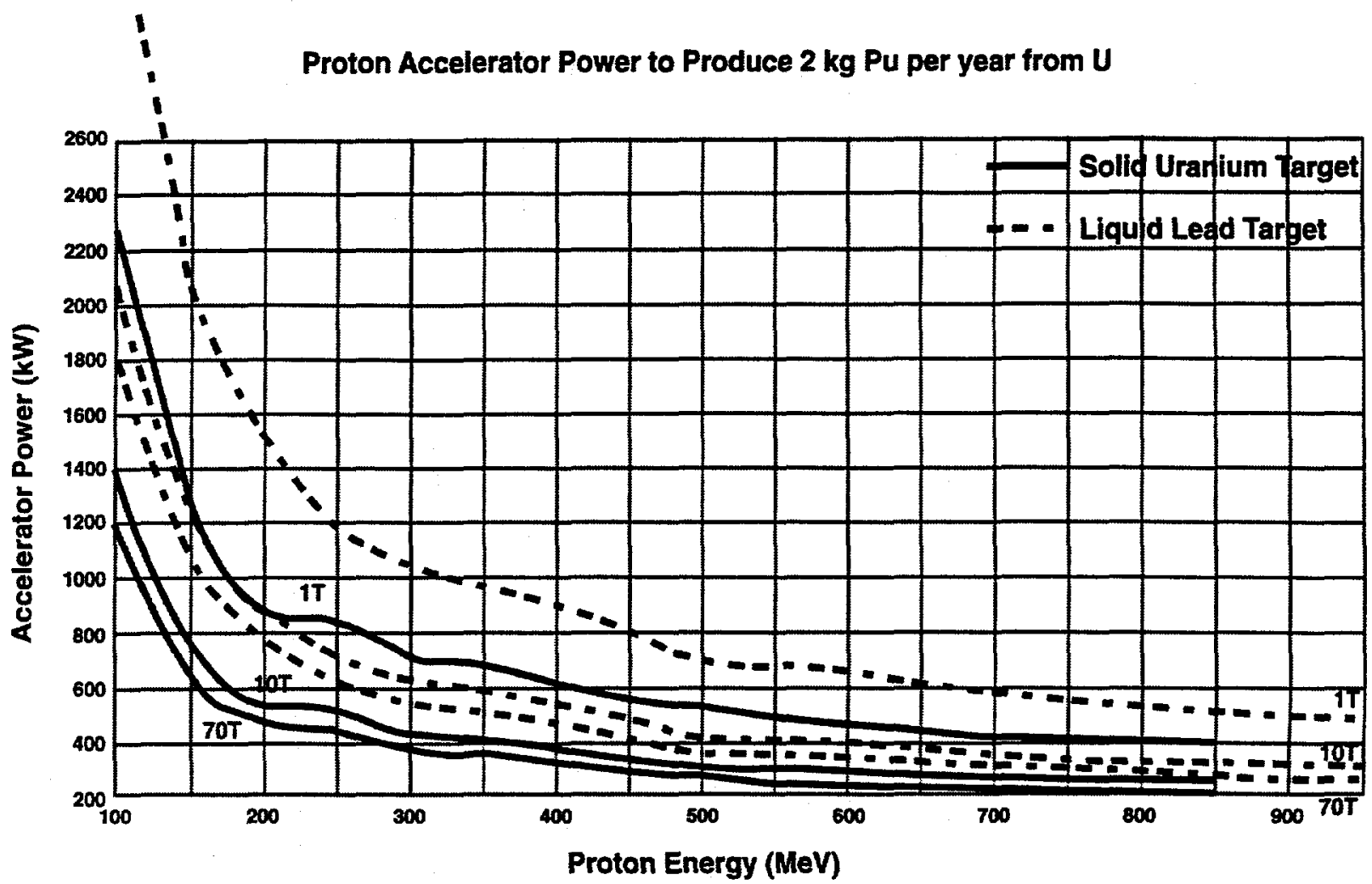

Fig. 5. Spallation neutron accelerator power vs energy.

Table 11. Accelerator power as a function of proton energy

\begin{tabular}{c|cc|cccccc}
\hline \multirow{2}{*}{$\begin{array}{c}\text { Proton } \\
\text { energy } \\
(\mathrm{MeV})\end{array}$} & $\begin{array}{c}\text { Neutrons per } \\
\text { proton }\end{array}$ & \multicolumn{5}{|c}{ Proton accelerator power $(\mathrm{kW})$ at a uranium loading of } \\
\cline { 2 - 8 } & $207 \mathrm{~Pb}$ & ${ }^{238} \mathrm{U}$ & \multicolumn{2}{|c|}{1 metric ton } & \multicolumn{2}{c}{10 metric tons } & \multicolumn{2}{c}{70 metric tons } \\
\hline 100 & 0.4 & 0.6 & 3445 & 2297 & 2083 & 1389 & 1803 & 1202 \\
200 & 1.8 & 3.0 & 1531 & 919 & 926 & 555 & 801 & 481 \\
300 & 3.9 & 5.7 & 1060 & 725 & 641 & 439 & 555 & 379 \\
400 & 6.2 & 9.0 & 889 & 612 & 538 & 370 & 465 & 320 \\
500 & 10.0 & 13.1 & 689 & 526 & 417 & 318 & 361 & 275 \\
600 & 12.9 & 17.5 & 641 & 472 & 388 & 286 & 335 & 247 \\
700 & 17.0 & 22.2 & 567 & 434 & 343 & 263 & 297 & 227 \\
800 & 21.3 & 27.2 & 518 & 405 & 313 & 245 & 271 & 212 \\
900 & 26.1 & $>30$ & 475 & $>410$ & 287 & $>250$ & 249 & $>215$ \\
\hline
\end{tabular}


Table 12. Spherical subcriticals: $\boldsymbol{k}_{\text {eff }}$ for various loadings of uranium

\begin{tabular}{cccc}
\hline \multirow{2}{*}{ Temperature } & \multicolumn{3}{c}{ Loading (metric tons) } \\
\cline { 2 - 4 } & 1 & 10 & 70 \\
\hline Hot & 0.73923 & 0.82870 & 0.86069 \\
Warm & 0.74970 & 0.83770 & 0.86974 \\
Cold & 0.76328 & 0.85035 & 0.88259 \\
\hline
\end{tabular}

Table 13. Spherical subcriticals: multiplication $(M)$ for various loadings of uranium

\begin{tabular}{cccc}
\hline & \multicolumn{3}{c}{ Loading (metric tons) } \\
\cline { 2 - 4 } Temperature & 1 & 10 & 70 \\
\hline Hot & 3.84 & 5.84 & 7.18 \\
Warm & 4.00 & 6.16 & 7.68 \\
Cold & 4.22 & 6.68 & 8.52 \\
\hline
\end{tabular}




\section{Conclusions}

The key parameters of the accelerator which affect plutonium production are particle beam current and particle energy. The production rate of plutonium is strongly dependent on system design. The conclusions of this study show that the production rate is proportional to beam power (the product of beam current times the energy of the incident particle) over a fairly wide energy range $(0.3 \mathrm{GeV}$ to at least $10 \mathrm{GeV})$. Below about $0.15 \mathrm{GeV}$, the spallation neutron production rate declines rapidly, making such designs quite ineffective. Therefore, our concern is concentrated on a particular class of accelerators at high energies. High-energy particle accelerators do not require high-technology blankets to produce sufficient quantities of plutonium to be of concern. Mediumenergy particle accelerators, including cyclotrons, are also a feasible means of producing plutonium, but these need to be enhanced by high levels of blanket multiplication to produce quantities of plutonium sufficient to be of concern.

The ORNL calculations demonstrate that the use of metal fuel in optimized blanket lattices allows the use of high-energy proton accelerators with beam powers as low as a few tens of kilowatts to produce $2 \mathrm{~kg} /$ year of plutonium. The ANL calculations show that high-energy proton accelerators capable of producing above $250 \mathrm{~kW}$ of beam power can be used without subcritical pile optimization for producing $2 \mathrm{~kg} /$ year of plutonium from natural uranium oxide cooled by light water. Very high multiplication $(>50)$ in the blanket lattice may not be desirable because the system then approaches a critical reactor and may not be sufficiently safe from a criticality standpoint after plutonium builds up.

Heat removal requirements for high power density have yet to be fully examined but may not be a significant concern since the blankets would be operating at low power densities. Other factors to take into account are technical aspects of the target design (such as net neutron production from spallation and multiplication in target material and the target system neutron leakage) and of the blanket design (such as blanket lattice multiplication; plutonium production efficiency in the blanket lattice; and reactivity feedbacks in the blanket, including xenon poison production and increased temperatures if the blanket is operated at high power densities).

Given the results of the calculations by ANL and ORNL, there are a number of accelerator facilities in the world which meet the requirements of accelerator power and beam energy and would be theoretically capable of producing quantities of plutonium that would be of proliferation concern within 1 year. Medium-energy particle accelerators, including cyclotrons, are a feasible and commercially available means of producing plutonium. Several known commercial accelerator design consultants may be capable of designing suitable systems. These accelerators need to be enhanced by high levels of blanket multiplication to produce quantities of plutonium sufficient to be of concern. Set up this way, the blanket acts as a subcritical reactor. 


\section{Recommendations for Further Study}

The major focus of future work should be to identify equipment and technologies that are most critical to the design, fabrication, construction, and operation of accelerator-driven systems that can be used for the production of fissile material. However, additional analyses are needed to better examine the capabilities of a few selected blanket designs that are the most likely candidates for consideration by a potential proliferator. The work would benefit greatly from quantifying the effects of thermal-hydraulic and structural-mechanical aspects of target design on plutonium production. For lower-energy particle accelerators using high-multiplication blankets, additional studies are needed to quantify precisely the effects of blanket feedbacks, including the effects of xenon and temperature, on production levels. The effect of blanket structures and structural materials must be quantified for the water-moderated, water-cooled blanket optimized for maximum subcritical multiplication. Finally, some effort is needed to quantify the proliferation potential, if any, of heavyion accelerators and ion-implantation devices that would operate at lower energies and might potentially take advantage of specific nuclear interaction thresholds that may exist for very heavy metal atom targets and heavy ions. 


\section{References}

1. C. M. Van Atta, "A Brief History of the MTA Project," Proceedings of an Information Meeting on Accelerator Breeding, Held at Brookhaven National Laboratory, January 18-19, 1977, CONF-770107, U.S. Energy Research and Development Administration, Washington, DC, 1977.

2. Status of the MTA Process, LRL-102 (Del.), Livermore Research Laboratory, Livermore, CA, February 1954.

3. J. S. Fraser, C. R. J. Hoffmann, and P. R. Tunnicliffe, Role of Electrically Produced Neutrons in Nuclear Power Generation, AECL-4658, Atomic Energy of Canada Ltd., Chalk River Nuclear Laboratories, Chalk River, Ontario, October 1973.

4. G. A. Bartholomew et al., Accelerator Breeder Concept, AECL-6363, Atomic Energy of Canada Ltd., Chalk River Nuclear Laboratories, Chalk River, Ontario, October 1978.

5. J. S. Fraser et al., A Review of Prospects for an Accelerator Breeder, AECL-7260, Atomic Energy of Canada Ltd., Chalk River Nuclear Laboratories, Chalk River, Ontario, December 1981.

6. V. G. Vasil'kov, V. I. Gol'danskii, V. P. Dzhelepov, and V. P. Dmitrievskii, "The Electronuclear Method of Generating Neutrons and Producing Fissionable Materials," translated from Atomnaya Énergiya, 29, No. 5, pp. 151-158, September 1970, published in English in Soviet Atomic Energy, Consultants Bureau, New York.

7. V. A. Davidenko, "On Electronuclear Breeding," translated from Atomnaya Énergiya, 29, No. 5, pp. 158-162, September 1970, published in English in Soviet Atomic Energy, Consultants Bureau, New York.

8. R. A. Lewis et al. (ANL), "A Preliminary Study of an Accelerator-Breeder Concept," Transactions of the American Nuclear Society, 28, p. 754, June 18-22, 1978, La Grange Park, IL (summary of an Argonne National Laboratory undistributed internal report, RSS-TM-8, November 1, 1977).

9. M. Steinberg et al., Linear Accelerator-Breeder (LAB): A Preliminary Analysis and Proposal, BNL-50592, Brookhaven National Laboratory, Upton, NY, November 10, 1976.

10. H. Takahashi and H. Ludewig (BNL), "Analysis of an Accelerator-Driven Reactor," Transactions of the American Nuclear Society, 27, p. 432-433, November 27-December 2, 1977, La Grange Park, IL. 
11. P. Grand et al. (BNL), "Linear Accelerator Driven and Regenerative Reactor Systems," and H. Takahashi (BNL), "Uranium and Thorium Fuel Cycle in Linear Accelerator Driven and Regenerative Reactors," Transactions of the American Nuclear Society, 28, p. 757-758 and 759-760, June 18-22, 1978, La Grange Park, IL.

12. C. M. Van Atta, J. D. Lee, and W. Heckrotte, The Electronuclear Conversion of Fertile to Fissile Material, UCRL-52144, Lawrence Livermore Laboratory, Livermore, CA, October 11, 1976.

13. R. E. Malenfant (LASL), "Electro-Nuclear Fuel Producer," Transactions of the American Nuclear Society, 28, p. 758-759, June 18-22, 1978, La Grange Park, IL.

14. J. S. Gilmore (LANL), "Fertile-to-Fissile and Fission Measurements for Depleted Uranium and Thorium Bombarded by 800-MeV Protons," Nuclear Science and Engineering, 99, No. 1, pp. 41-52, May 1988.

15. F. R. Mynatt et al., Preliminary Report on the Promise of Accelerator Breeding and Converter Symbiosis (ABACS) as an Alternative Energy Option, ORNL/TM-5750, Oak Ridge National Laboratory, Oak Ridge, TN, February 1977.

16. T. J. Burns, D. E. Bartine, and J. P. Renier, Concept Evaluation of a Nuclear Design for Electro-nuclear Fuel Production: Evaluation of ORNL's Proposed TMF-ENFP, ORNL/TM6828, Oak Ridge National Laboratory, Oak Ridge, TN, 1979.

17. J. O. Johnson, T. A. Gabriel, and D. E. Bartine, Accelerator Breeder Nuclear Fuel Production: Concept Evaluation of a Modified Design for ORNL's Proposed TMF-ENFP, ORNL/TM-8999, Oak Ridge National Laboratory, Oak Ridge, TN, July 1986.

18. On the Internet: "Overview of the ATW System," at address: http://neutrino.nuc.berkeley.edu/designs/atw/Overview.html

19. O. V. Shvedov et al., "Weapon Plutonium in Accelerator Driven Power System," pp. A1-A60, Russian-authored appendix to the Joint United States/Russian Plutonium Disposition Study, September 1996.

20. On the Internet: "Accelerator Driven Systems (ADS)," at address: http://itumagill.fzk.de/ADS/

21. On the Internet: T. Takizuka et al., "Accelerator-Driven Transmutation," at address: http://inisjp.tokai.jaeri.go.jp/ACT95E/11/11-3.HTM

22. E. D. Arthur, A. Rodriguez, and S. O. Schriber, Editors, AIP Conference Proceedings 346: International Conference on Accelerator-Driven Transmutation Technologies and Applications, Las Vegas, NV, July 1994, LA-UR-95-1792, Los Alamos National Laboratory, published by

- AIP Press, American Institute of Physics, Woodbury, NY, 1995.

23. On the Internet: "U.S. Accelerator Production of Tritium (APT) Project," at three addresses: http://www.srs.gov/general/news-notes/tritium_accel/accelerator.html; 
http://necs01.dne.bnl.gov/atd-mag/apt.html; and http://apt.lanl.gov/

24. On the Internet: "French Tritium from Spallation (TRISPAL) Project," described in a paper at the following address:

http://wwwlab.cern.ch/CERN/Divisions/PS/Linac96/Proceedings/Monday/MO102/Paper.html

25. Yu.Ya. Stavissky, "Subcritical Nuclear Reactors Driven with High-Current Proton Accelerators," Preprint INR-0901/95, Russian Academy of Sciences Institute of Nuclear Research, Moscow, July 1995.

26. V. N. Aseev et al., "Subcritical Channel-Type Reactor for Weapon Plutonium Utilization," Second International Conference on Accelerator-Driven Transmutation Technologies and Applications, Kalmar, Sweden, June 3-7, 1996.

27. M. A. Lone, Thick Target Neutron Yields from Spallation Reactions, AECL-10599, Chalk River Nuclear Laboratories, Chalk River, Ontario, 1992.

28. N. F. Landers and L. M. Petrie, CSAS: Control Module for Enhanced Criticality Safety Analysis Sequences, NUREG/CR-0200, Oak Ridge National Laboratory, Oak Ridge, TN, 1995.

29. J. Briesmeister (Editor), MCNP-A General Monte Carlo Code N-Particle Transport Code Version 4A, LANL-12212, Los Alamos National Laboratory, Los Alamos, NM, 1993.

30. W. E. Ford III et al., ANSL-V: ENDF/B-V Based Multigroup Cross-Section Libraries for Advanced Neutron Source (ANS) Reactor Studies, ORNL-6618, Oak Ridge National Laboratory, Oak Ridge, TN, 1990.

31. K. C. Chandler and T. W. Armstrong, Operating Instructions for the High-Energy NucleonMeson Transport Code HETC, ORNL-4744, Oak Ridge National Laboratory, Oak Ridge, TN, 1972.

32. Directory of Nuclear Reactors, Vol. IV, Power Reactors, International Atomic Energy Agency, Vienna, 1962 ("G2 \& G3," pp. 191-195).

33. Directory of Nuclear Reactors, Vol. VII, Power Reactors, International Atomic Energy Agency, Vienna, 1968 ("N-Reactor," p. 115).

34. Directory of Nuclear Reactors, Vol. I, Power Reactors, International Atomic Energy Agency, Vienna, 1959.

35. Directory of Nuclear Reactors, Vol. II, Research, Test, \& Experimental Reactors, International Atomic Energy Agency, Vienna, 1959.

36. Directory of Nuclear Reactors, Vol. III, Research, Test, \& Experimental Reactors, International Atomic Energy Agency, Vienna, 1960. 


\section{DISTRIBUTION:}

P. Rosen, SC-20

B. Weakley, SC-4

R. Gottemoeller, NN-1

L. Spector, NN-40

B. Richter, Director, Stanford Linear Accelerator Center

W. Panofsky, Stanford Linear Accelerator Center

A. Trivelpiece, Director, Oak Ridge National Laboratory

D. Moncton, ORNL Spallation Neutron Source Project Director

F. Fradin, Interim Director, Argonne National Laboratory

J. Marburger, Director, Brookhaven National Laboratory

C. Shank, Director, Lawrence Berkeley National Laboratory

J. Browne, Director, Los Alamos National Laboratory

\section{ADDITIONAL DISTRIBUTION BY OAK RIDGE:}

U.S. Department of Energy

G. Blanchard, ORO/DP-50

P. Dedik, NN-43

R. Goorevich, NN-43 (2)

Z. Hollander, NN-43 (2)

C. Riendeau, NN-43 (5)

L. Spector, NN-40

L. Watkins, ORO/DP-1

R. Williams, $\mathrm{IN}-1$

Site Office, ORNL

Argonne National Laboratory

A. Olson, TD (5)

Los Alamos National Laboratory

J. Bedell, NIS (5)

A. Lundy, NIS
Oak Ridge National Security Program Office

S. Baker

K. Cross

D. Langenberg

L. Satkowiak

O. Stansfield

J. Turner

R. Upchurch

J. Whitaker

Oak Ridge National Laboratory

A. Akerman, ETD (2)

J. Drischler, CPED

J. Gehin, CPED

J. Johnson, CPED

R. Lillie, CPED

D. Moses, ETD (5) 